CREDIT Research Paper

No. 10/02

\title{
Budget Institutions and Fiscal Performance in Africa
}

\author{
by \\ Sophia Gollwitzer \\ The Graduate Institute, Geneva
}

\begin{abstract}
This paper develops an index measuring the adequacy of the institutions, rules and procedures governing the budget process in 46 African countries, presenting the most comprehensive analysis of African budget institutions hitherto conducted. The index includes the three stages of the budget process: negotiation, legislative approval, and implementation. At each stage the quality of the budget process is measured along five criteria: centralization, rules and controls, sustainability and credibility, comprehensiveness, and transparency. A wide dispersion in institutional quality is found across the continent. Furthermore, an empirical analysis based on OLS estimations shows that better budget institutions are associated with lower public external debt and a higher primary budget balance.
\end{abstract}

JEL Classification: H61, H62, H63, E62

Keywords: Budget Institutions, Budget Systems, African Countries, Fiscal Policy

\section{Centre for Research in Economic Development and International Trade, University of Nottingham}




\title{
CREDIT Research Paper
}

No. $10 / 02$

\section{Budget Institutions and Fiscal Performance in Africa}

\author{
by \\ Sophia Gollwitzer \\ The Graduate Institute, Geneva
}

\begin{abstract}
A. Outline
\end{abstract}
1. Introduction

2. Background

3. Relevant Literature

4. Index Construction

5. Data Sources

6. Aggregation of the Index

7. Empirical Analysis

8. Concluding Remarks

References

Appendices

Research Papers at www.nottingham.ac.uk/economics/credit/ 


\section{INTRODUCTION}

Fiscal institutions comprise the policies, rules and procedures of the public revenue and expenditure process thus representing the most important macroeconomic commitment institutions for governments. This paper focuses mostly on the expenditure side of fiscal institutions, referring to the associated policies, rules and procedures as budgetary institutions (BI) thereby following the definition of Alesina and Perotti (1996). ${ }^{1}$ It proposes the construction of an index which allows for the assessment of the adequacy of BI in the specific context of African countries. ${ }^{2}$

Since the seminal paper by von Hagen (1992) a rapidly increasing literature has focused on the appropriate design of budget institutions and their role in enhancing fiscal discipline. Most of the literature, however, has concentrated on budget institutions and fiscal policies in European Union member states with the exception of Alesina et al. (1996 and 1999) who analyze budget institutions in Latin America. Little has been written on Africa, mainly because until recently only very limited information was available on African fiscal policies and procedures. This paper intends to close this gap by quantifying the quality of BI in the member states of the African Union (AU) and Morocco (which is not a member of the AU) in an index and by analyzing their impact on fiscal outcomes.

Clearly, the AU member states are a very heterogeneous group of countries in which per capita GDP ranged from US\$ 144 in Burundi to US\$28,103 in Equatorial Guinea in 2008 and Human Development Index (HDI) rankings from the lowest in the world for Niger (182)

\footnotetext{
Note that the process of revenue collection is not analyzed in the present index as the effectiveness of this process is only partially influenced by institutional quality and is also subject to the quality of infrastructure, technology, and the size of the informal economy - all factors that cannot be easily changed by the government in the short-run. This means that the quality of revenue collection is not necessarily representative of the quality of the governmental BI - which is what I intend to measure with my index.

2 This paper (and earlier versions of this paper) is the basis for a research project at the IMF conducted jointly with Era Dabla Norris, Eteri Kvintradze, Tej Prakash, Felipe Zanna, Victor Lledo and Irene Yackovlev (see IMF WP/10/80) which applies a modified version of the index to a larger group of developing and emerging countries. For the IMF study several of the Africa-specific sub-criteria of the index have been adjusted or deleted and replaced by more general LIC-specific criteria.
} 
to high human development in Libya, the Seychelles and Mauritius in 2009. ${ }^{3}$ Yet, given the recent ambitions to transform the African Union into an economic union and a political federation, a pan-African analysis of budget institutions seems appropriate in two ways: first, it helps to highlight the intra-continental differences and the need for convergence; second, and more importantly, an intra-African comparison of institutional quality can provide the basis for the evaluation of continent-wide reform programs and ambitions. The paper analyzes African budgetary systems in isolation given that the region's comparatively high vulnerability to external shocks, large extent of external influence, underdeveloped financial markets, and weak state structures and political systems render the fiscal position of African countries generally more fragile than that of other developing countries. Therefore measures that lead to desirable fiscal outcomes in other low-income countries may not have the same effect in African countries. So far, the only exclusively African analysis of budget practices has been conducted by the Collaborative African Budget Initiative (CABRI) in 2008. However, the study only includes 26 countries and is based entirely on country surveys. My index, on the other hand, is based on a variety of surveys and external analyses and includes 46 African countries.

It is found that there are indeed big differences in the quality of budgetary institutions on the continent. Furthermore, sound BI are associated with lower public external debt levels andless significantly-a higher primary budget balance. The remainder of the paper is structured as follows. Section II provides the background on budget institutions in Africa. Section III briefly surveys the relevant literature. In Section IV, the index is constructed. Section V discusses the data sources. Section VI presents three alternative techniques for the aggregation of the index. The empirical analysis is described in section VII. Section VIII concludes.

$3 \quad$ World Bank, World Development Indicators, 2009. 


\section{BACKGROUND}

In Africa, budgetary frameworks have usually been taken over from the colonial powers and then formally stayed in place for several decades without significant adjustments to the country- and period-specific circumstances. Overall, African countries inherited very fragile systems of public finance with narrow tax bases and heavy dependency on customs duties and export taxes. ${ }^{4}$ At the same time, pressures to increase public spending (especially on infrastructure and the social system) were very strong. Government expenditure grew rapidly in the years following independence, quickly outgrowing revenue expansion. While some of this expenditure was urgently needed, a great part of resources was wasted. Siebritz and Calitz (2006) state that the major problems were "politically motivated expansion of public employment and excessive intervention in economic activity aimed at accelerating the process of development and industrialization". ${ }^{5}$ Heavy government subsidies to loss-making enterprises combined with political instability, a lack of expertise, and a distressing tendency of public officers to amass personal fortunes by looting their country's resources greatly aggravated the situation. During the 1970's, the average public deficit of African countries was 6.4 percent, whereas at the same time Latin America and Carribean countries averaged at 4.6 percent and the OECD countries at 1.2 percent. African governments financed a large share of their deficits through external debt and as a result debt service payments rose sharply. With the trade shocks and weak growth in export demand following the global slowdown in economic growth and the second oil price shock in 1979 and 1980, the situation became unmanagable. External debt and debt service payments skyrocketed. ${ }^{6}$ Heavy reliance on trade revenues, a lack of alternative policy instruments, and fragility of the fiscal balance characterized African fiscal policies in this period.

For a detailed overview of fiscal policy in sub-Saharan Africa between 1950 and 2005, see Siebritz and Calitz (2006).

Siebritz and Calitz (2006).

By 1985 the average sub-Sahran African country faced a debt burden of over 50 percent of GDP (see Sibritz and Calitz, 2006). 
Given the deteriorating macroeconomic situation and diminishing access to private foreign capital, African governments increasingly sought help at the World Bank and the IMF. These loans were tied to major structural reforms. The two Bretton Woods institutions developed frameworks for improved public expenditure management, the most widely propagated of which were the so-called Medium-Term Expenditure Frameworks (MTEF). MTEFs are intended to link policy planning and -making with budgeting and, as the name suggests, to encourage medium-term planning to enhance the sustainability of expenditure policies. ${ }^{7}$ Between 1992 and 2001, 13 African countries formally adopted MTEFs-with the exception of Namibia, all of them under the aegis of the World Bank. ${ }^{8}$ While the implementation record of the structural adjustment was generally relatively poor, ${ }^{9}$ major political reforms at the national level, as well as the launch of the HIPC debt relief initiative, led to significant improvements in the budget balances in many African countries from the mid-1990's onwards. By 2004, 18 African countries had achieved grant inclusive budget surpluses. ${ }^{10}$

However, fiscal policy in African countries remains more fragile on average than in other developing countries. Narrow tax bases, relatively small private capital inflows, and underdeveloped financial markets leave African countries highly dependent on grants and foreign loans for financing government expenditure. These aid receipts have been shown to be very volatile. ${ }^{11}$ Moreover, the one-dimensionality of the industrial base of most African countries, which rely heavily on the export of raw materials, renders the region extremely vulnerable to external shocks. This vulnerability, combined with the continued pressure to increase

7 Generally, an MTEF requires multiannual budget planning based on a macroeconomic and fiscal framework and on sectoral programs and expenditure frameworks.

8 The follwing countries have formally adopted MTEFs: Benin, Burkina Faso, Gabon, Ghana, Guinea, Kenya, Malawi, Mozambique, Namibia, Rwanda, South Africa, Tanzania and Uganda. South Africa, Uganda and Tanzania adopted the most comprehensive frameworks.

$9 \quad$ See Sibritz and Calitz (2006) for details.

$10 \quad$ See Sibritz and Calitz (2006).

11 UNECA (2009) shows that aid receipts in sub-Saharan Africa are two times more volatile than tax revenue receipts. 
government expenditure on infrastructure- on social sector projects, renders any gains in the fiscal position of the average African country extremely frail.

It was against this background that, between 2004 and 2009, a steadily increasing number of African countries launched an initiative for the advancement of budget reforms, CABRI, which was formally established in cooperation with the African Development Bank in 2008. CABRI is an African senior budget-officials network. The current 31 member states aim to improve the efficiency of budget and financial management by sharing knowledge and experiences on reform programs. They also aim for coordinated regional approaches in key areas of the budget process. Together with the OECD, CABRI has started to conduct extensive surveys on budget procedures and practices in African countries. This paper attempts to facilitate the formal analysis of African budget processes thereby drawing both on the information collected by CABRI and on a variety of other sources.

\section{RELEVANT LITERATURE}

\section{A. Quantifying the Quality of Budget Institutions}

Since the early 1990s, various attempts have been made to define numerical indices capturing the most relevant qualitative aspects of budget institutions. Von Hagen (1992) and Harden and von Hagen (1994) constructed an index measuring the level of centralization in the budget process arguing that a centralized budget process enhances fiscal discipline. Studying the design of fiscal rules for European countries, Hallerberg and von Hagen (1999) and Hallerberg, Strauch and von Hagen (2004) argue that one index is not appropriate for all countries. They identify the availability of two distinct institutional approaches to overcome the deficit bias in public budgeting. The first is the delegation approach, which is defined as the delegation of power to the minister of finance and corresponds to the older concept of centralization. The second is the contract approach, which consists of pre-established budgetary targets and rules. The choice and optimality of the two approaches is countryspecific and depends on the prevalence of a single-party versus a coalition government in the individual country. 
Several recent studies build on the findings of von Hagen et al.. Fabrizio and Mody (2006) measure the quality of BI in a quantitative index capturing checks and balances through hierarchical rules and collegiality for ten new and potential EU member states between 1997 and 2003. They find that the quality of budgetary institutions matters strongly in determining fiscal outcomes. While each of the components of their BI index has a strong and independent force, the implementation stage of the budgetary process appears to be the most relevant stage. Furthermore, political variables seem to have a greater influence on the budgetary outcome than economic variables. Mulas-Granados et al. (2009) develop indices for budget institutions to analyze the effect of BI on fiscal consolidation as observed through public finances in the new EU member states. Like Fabrizio and Mody (2006) they find that budgetary institutions have a significant impact on fiscal performance.

The above indices were developed for and applied to European and other high income countries and therefore reflect many characteristics of fiscal policies and mechanisms in these countries. ${ }^{12}$ They are therefore not directly applicable to measuring the institutional quality of the budget process in developing countries. As Schick (1998) rightly argues, "the budgetary predicament of poor developing countries is fundamentally different from that of rich developed countries [...]. Prescriptions and processes that are appropriate for the latter may hold disappointing results in the former". ${ }^{13}$ The next sub-section describes some of the problems related to the budget process in low-income countries (LICs).

Various studies have applied adjusted versions of the general von Hagen framework to LICs. But the lack of data on budgetary rules and procedures in developing countries has significantly limited the quantity and depth of studies in this field. Alesina, Hausman,

12 For example, Mulas-Grandaos et al. (2009) define intervention by the Prime Minister as best practice for the resolution of conflicts between the Minister of Finance and Parliament. Similiarly, Fabrizio and Mody (2006) only award the relative strength of the executive vis a vis the parliament. These practices are clearly suboptimal in regimes that are not fully democratic where a stronger parliament may actually provide the mechanism to controll excessive spending by the executive. Furthermore, none of the above indices considers the inclusion of aid in the budget and time periods for approval and reports are designed for the infrastructure of EU countries. 
Hommes and Stein (1999) were the first to formally measure the quality of budget institutions in developing countries. They construct an index of BI in Latin American and Caribbean countries, thereby building on the early von Hagen approach and find that fiscal constraints and hierarchical and transparent procedures did promote fiscal discipline in Latin American and Caribbean countries. Prakash and Cabezon (2008) measure the quality of public financial management (PFM) by constructing an index, based on the heavily indebted poor countries (HIPC) PFM dataset capturing the quality of budget formulation, execution and reporting for 22 African countries. They find that the quality of PFM matters for fiscal balances and the external debt. Yet, their analysis is limited to the aspects considered by the HIPC PFM survey and thus is incapable of capturing all relevant aspects of budget institutions as the PFM surveys focus mainly on the operational performance of the key elements of the PFM systems, rather than the legal framework and the strategic interactions between the various actors at different stages of the budget process. To my knowledge, not a single study has previously attempted to measure the quality of budget institutions in a larger sample of African countries than Prakash and Cabezon (2008).

\section{B. Origins of the Deficit Bias in LICs in General and African Countries in Particular}

The need for sound budget institutions derives from the deficit bias in public financial management, a phenomenon which is well-established, both theoretically and empirically. This bias originates from several different factors. While some of these appear across all regions and stages of economic development, LICs face a number of additional difficulties related to the budget process. The following paragraphs summarize the most prominent budgetary malpractices typically found in LICs.

A phenomenon faced by policymakers irrespective of their country's income-level is the common pool problem, as established by Harden and von Hagen (1995) and Hallerberg and von Hagen (1999), which arises when the various decision makers involved in the budgetary process compete for public resources and thereby fail to internalize the current and future costs of their choices. ${ }^{14}$ The situation is aggravated if, as is the case in many African

\footnotetext{
14 See Krogstrup and Wyplosz (2006) for a more recent approach to the common pool problem.
} 
countries, numerous ministries fight for very limited resources. Another universal explanation for the deficit bias is offered by the theory on time inconsistency of preferences, as introduced by Alesina and Tabellini (1990). This theory argues that governments facing electoral uncertainty and disagreement with rivaling policymakers will fail to fully internalize the costs of leaving debt to succeeding governments. Yet another general reason for excessive fiscal expenditure is the so-called optimism bias. The recent literature has found a bias towards systematic overestimation of economic and fiscal developments in fiscal forecasts produced by governments. ${ }^{15}$ The volatility of the mostly export-oriented African economies makes long-term planning difficult and forecasts unreliable. In planning the annual budget, governments tend to ignore these volatilities and to plan the budget on the basis of a best-case scenario. The underlying assumptions tend to be overly optimistic and the budget often has to be adjusted to the actual economic situation.

Turning to more LIC-specific challenges encountered during the budget process, the agency problem, summarized by Persson and Tabellini (2000), arises if rent-seeking politicians appropriate resources for themselves at the cost of the citizens. Schick (1998) describes further typical cases of misrouted budget management observed in African and other lowincome countries - most of them at least partially associated with the government's rent seeking behaviour. These include unrealistic budgeting, where the approved budget is commonly accepted as a farce; hidden budgeting, where the real budget is known only to a selected few; escapist budgeting, where the government authorizes expenditures knowing that they will never occur; repetitive budgeting, where the budget is revised frequently during the fiscal years to adjust to the current needs and restraints; short-term budgeting, where budgets are made for one year without considering the medium- or longer term implications; and corruption which arises "when formal rules are unworkable and government operates through extra-legal means". ${ }^{16}$

While most developing countries encounter one or more of the above challenges, African countries tend to be affected by several of these malpractices to a specifically large extent.

\footnotetext{
15 For an overview of the literature see International Monetary Fund (2010).

$16 \quad$ Schick (1998): p.36 - 41
} 
The agency problem is certainly one of the central problems throughout the budget process in many African countries, where government positions are still largely associated with the opportunity to amass a personal fortune. This tendency is reinforced by the comparatively weak political systems in Africa where the continuity and stability of political regimes are extremely limited which in turn promotes a "après nous le déluge" attitude. The same reasons may also explain why African countries rank lower on average than American and Asian LICs in the Transparency International Corruption Perception Index. ${ }^{17}$ Unrealistic and escapist budgeting are practices that may be aggravated by external pressure to increase public expenditure in certain sectors. The significant involvement of the IMF in most African countries and the associated structural reforms and requirements may induce governments to include expenditures in the planned budget that comply with these requirements, although they are unlikely to be affordable. Finally, in spite of the introduction of medium-term expenditure frameworks in many African countries, short-term budgeting is still a widespread malpractice on the continent which may be explained by a volatile macroeconomic environment in which it is very difficult to plan ahead over a longer period of time. In this difficult budgetary environment, aspects such as the precise design of a MTEF or the precision of a macroeconomic planning framework will play a far more important role than in more advanced or more stable regions and therefore have to be considered more thoroughly when assessing the quality of BI.

$17 \quad$ See Transparency International Global Corruption Perception Index 2009. 


\section{INDEX CONSTRUCTION}

This paper constructs an Africa-specific BI index. Unlike existing indicators, my index provides a framework for a two-dimensional analysis across budgetary phases and across categories. I follow the literature in distinguishing between three phases of the budget process. The negotiation and planning phase (phase 1) comprises the establishment of the overall budget, the allocation of funds between the different line ministries and programs, and the construction of multi-annual macroeconomic and budgetary frameworks. The legislative approval phase (phase 2) consists of the legislature's hearing of and vote on the annual budget including overall budget policies and specific allocations. The implementation phase (phase 3) includes the execution, control and reporting of budgetary allocations.

At each of the three budgetary phases, the index captures five categories evaluating different aspects of the quality of budget institutions. These categories include centralization, rules and controls, sustainability and credibility, comprehensiveness, and transparency. Each category is made up of several individual criteria (34 in total) as shown in Tables 1 through 5. Table A-I 1 in the appendix depicts the detailed scoring scheme for all index components. The data sources are discussed further in the subsequent section.

\section{A. Centralization}

The most commonly used criterion for the evaluation of public financial management is centralization. Harden and von Hagen (1994) maintain that the common pool problem and thus excessive fiscal deficits could be reduced by introducing elements of centralization, which they define as "institutional structures that strengthen a comprehensive view of the budget over the particularistic view of the spending ministers and the members of parliament", into the budget process. ${ }^{18}$ Similarly, Alesina and Perotti (1996) distinguish between hierarchical and collegial procedures. In hierarchical procedures, the minister of finance is more powerful, whereas under collegial rules, the line ministries play a greater role. They find that more hierarchical systems are associated with greater fiscal discipline.

$18 \quad$ Harden and von Hagen (1994). 
Mulas-Granados et al. (2009) confirm the positive impact of a strong finance minister on fiscal outcomes for Eastern European countries. Prakash and Cabezon (2008) find that hierarchical systems seem to promote fiscal discipline in sub-Saharan Africa. Drawing on these findings, I define centralization as the extent to which the central budget authority is given the leading role in maintaining aggregate fiscal discipline, ensuring compliance with the budget laws, and enforcing controls of budgetary expenditures. ${ }^{19}$ The index includes five centralization criteria which are summarized in Table 1.

During phase 1, the level of centralization is measured according to the legal vesting of power and the structure of the budgetary agenda setting. Ideally, the minister of finance or another central budget authority should be clearly identified as primary general budget officer. The central budget authority should send out macroeconomic guidelines and spending ceilings or targets to the line ministries and should have the last word in case of a disagreement with the line ministries. This should help to curtail expenditure benefiting a few narrow constituencies at the expense of the general public. The optimal score for the structure of the agenda setting thus differs from best practice in OECD countries, where considerable responsibility and power of decision is granted to the individual line ministries. The assumption underlying the scoring scheme is that in most African countries the greatest expertise in budget management is concentrated in the ministry of finance, whereas the capability of structured fiscal planning in the line ministries is limited.

Centralization during phase 2 is evaluated along the legislature's power to amend the proposed budget and along the executive's veto power on legislative amendments. The maximum score for legislative amendments is granted if the legislature can neither increase spending nor create new expenditure items, but has the power to decrease proposed expenditure. The worst score is given both if the legislature has unlimited power and if it possesses no power to amend the budget. Likewise, for the second criterion under the budget

19 I follow Curristine and Bas (2007) in referring to the central budget authority (CBA) as the ministry or government agency which has "the leading role in maintaining aggregate fiscal discipline, ensuring compliance with the budget laws and enforcing effective control of budgetary expenditure". 
approval phase the worst score is given if the executive cannot veto amendments and if it possesses unlimited veto power. The optimal score is awarded if the executive can veto legislative amendments subject to strict regulations and limits. This reflects the idea that the legislature should have some influence in the budget process but that this influence should be limited to avoid undue indirect influence of pressure groups and constituencies and to avoid lengthy and inefficient negotiations. The explicit punishment of too little parliamentary influence and excessive veto power of the executive is required in a region where in 2008 the Economist Intelligence Unit's Democracy Index ranked 28 countries as authoritarian regimes and only one African country (Mauritius) as full democracy.

Finally, in phase 3, the specification for the disbursement of funds serves as indicator for the level of centralization. Ideally, every agency or executive organization should receive an appropriation from the CBA specifying expenditures below the agency level. Again, this score differs from best practice in OECD countries (where the agencies often receive lumpsum appropriations) and is based upon the assumption that in most African countries the best planning capabilities and the greatest expertise are concentrated in the ministry of finance.

Table 1: Centralization Criteria ${ }^{20}$

\begin{tabular}{|c|c|c|}
\hline BUDGET PHASE & CRITERIA & SOURCES \\
\hline Phase 1 & $\begin{array}{ll}- & \text { Legal Vesting of Power } \\
\text { - } & \text { Agenda Setting } \\
\end{array}$ & $\begin{array}{ll}\text { - } & \text { OECD, ROSC, IMF/ IBP Q's } \\
\text { - } & \text { OECD, PEFA, IMF/ IBP Q's }\end{array}$ \\
\hline Phase 2 & $\begin{array}{ll}\text { - } & \text { Amendments by Legislature } \\
\text { - } & \text { Executive Veto } \\
\end{array}$ & $\begin{array}{ll}\text { - } & \text { OECD, IBP, ROSC, IMF/ IBP Q's, NL } \\
\text { - } & \text { OECD, IMF/ IBP Q's, NL } \\
\end{array}$ \\
\hline Phase 3 & - $\quad$ Disbursement Specification & - $\quad$ OECD, IMF/ IBP Q's \\
\hline
\end{tabular}

\section{B. Fiscal and Procedural Rules and Controls}

The imposition of rules and controls on the budget process can help to alleviate the effects of the time inconsistency of preferences and the agency problem. Budgetary rules can be

20 OECD is the OECD International Budget Practices and Procedures Database, ROSCs are IMF Reports on the Observance of Standards and Codes, PEFA are Public Expenditure and Financial Accountability Program Reports, IBP is the International Budget Project Database, IMF/ IBP Q's are questionnaires sent out to IMF and/ or IBP country experts, and NL is national legislation, such as the constitution or budget laws. 
grouped into fiscal and procedural rules. Fiscal rules limit the ability of the central budget authority to accumulate debt and spend excessively by imposing a durable numerical restriction on a relevant fiscal variable. Many African countries have legally anchored fiscal consolidation objectives in the context of regional convergence criteria. The obvious disadvantage of strict fiscal rules is that they may significantly limit the government's policy space. In their paper on fiscal consolidation in G20 countries (IMF 2010) Blondy et al. identify four factors that contribute to successful fiscal rules: medium-term orientation, transparency, comprehensiveness in coverage and consistency in application. Nevertheless, numerical fiscal targets, due to their inflexibility, may not always be optimal from an economic perspective. They should therefore be complemented by procedural rules. These are rules and regulations governing the budgetary processes. They can serve as guarantee for the compliance of actual expenditure with the budget and reduce the likelihood of "war of attrition" scenarios. The obvious trade-off here is again between flexibility and commitment. Several studies find empirical evidence for a positive impact of rules and controls on fiscal performance. Alesina et al. (1999) find that binding constraints have the most important impact of their index components for the sample of Latin American countries. Poterba (1996) shows that balanced budget rules have the potential to determine expenditure outcomes in US states. Prakash and Cabezon (2008) also find a significant impact of budgetary rules on fiscal outcomes in sub-Saharan African countries.

My index comprises both fiscal and procedural rules. The former are measured by a criterion on the existence of numerical fiscal rules. The latter are captured by several criteria, as described below. During phase 1 the existence of numerical fiscal rules is evaluated. The legal commitment to a debt rule, possibly in combination with other fiscal rules, yields the highest score as it represents the strictest form of a fiscal rule. This rewards fiscal stabilization initiatives at the national and regional level. For example, the member countries of the West African Monetary Zone (WAMZ) project, which have accepted a four percent deficit to GDP limit as part of their convergence criteria obtain the second highest possible. Furthermore, the imposition of sectoral budget ceilings is rewarded. Ideally, budget ceilings should be imposed upon all line ministries for all types of expenditure. This greatly facilitates 
planning and avoids bargaining for excessive appropriations for individual ministries and projects thereby reducing the common pool problem.

Throughout phase 2 two procedural rules are considered. First, the time-frame for legislative approval is assessed. This period should be neither too short (as the legislature needs to be able to actually work through and discuss the entire budget) nor too long (as this encourages lengthy fruitless discussions which render the process inefficient). Ideally, the budget should be approved within two to three months after the executive's presentation of the proposal and prior to the start of the fiscal year. Second, the procedure which is followed in case the legislature fails to approve the budget is evaluated. Full points are only granted if expenditure without legislative approval is explicitly forbidden. The next best alternative is a legislative vote on interim measures.

For the third phase three procedural rules are examined. First, the index accounts for the existence of an external and legally independent audit body. This audit body should ideally publish reports on a regular basis and suggest sanctions in case of mal-performance. Second, the flexibility of the executive to increase expenditure during the fiscal year is assessed. To avoid repetitive budgeting, this should be forbidden with the exception of emergency expenditure (after a natural catastrophe or another big external shock). Finally, the third criterion rewards the imposition of sanctions in case of mal-performance. The stricter the sanctions, the more points are obtained. The highest score is granted if appropriations to an entire ministry may be reduced following the abuse of funds.

Table 2: Rules and Controls Criteria

\begin{tabular}{|c|c|c|}
\hline " BUDGET PHASE & " CRITERIA & SOURCES \\
\hline Phase 1 & $\begin{array}{ll}- & \text { Fiscal Rules } \\
\text { - } & \text { Sector Budget Ceilings } \\
\end{array}$ & $\begin{array}{ll}\text { - } & \text { OECD, ROSC, IMF/ IBP Q's } \\
\text { - } & \text { OECD, IMF/ IBP Q's }\end{array}$ \\
\hline Phase 2 & $\begin{array}{ll}\text { - } & \text { Time Limit for Approval } \\
\text { - } & \text { Procedure in Case of Failed Approval }\end{array}$ & $\begin{array}{ll}\text { - } & \text { OECD, ROSC, IMF/ IBP Q's, NL } \\
\text { - } & \text { OECD, ROSC, NL, IMF/ IBP Q's }\end{array}$ \\
\hline Phase 3 & $\begin{array}{ll}\text { - } & \text { Audit Body } \\
\text { - } & \text { Flexibility to Increase Funds } \\
\text { - } & \text { Sanctions for Poor Performance }\end{array}$ & $\begin{array}{ll}\bullet & \text { PEFA, IBP, IMF/ IBP Q's } \\
\text { - } & \text { OECD, PEFA, IMF/ IBP Q's } \\
\text { - } & \text { OECD, IMF/ IBP Q's }\end{array}$ \\
\hline
\end{tabular}




\section{Sustainability and Credibility}

Another way of reducing the problems associated with the time inconsistency of preferences is to introduce elements of sustainability and credibility into the budgetary framework. I consider four such elements. The aspect of sustainability that has been given most attention in the literature is the medium-term expenditure framework. Sound MTEFs are of particular importance for African countries given the risk for short-term budgeting in light of political and economic instability. Indeed MTEFs have been promoted widely in Africa with mixed success. The 2008 CABRI Report on Budget Practices and Procedures argues that while most countries included in their study claim to include multi-year targets in the budget process these vary greatly in usefulness including the fact that "these instruments were often introduced without taking into account the broader budgeting environment and existing capacity, the lack of medium-term projections for more predictable aid flows, and the existence of different legal and administrative traditions that might influence the feasibility of introducing a medium-term framework". I therefore add another criterion on robust macroeconomic and fiscal forecasting taking into account various scenarios and potential risks. In addition to improving the MTEF this also helps to overcome unrealistic budgeting and especially the optimism bias in budgetary planning and forecasts. The third element, comprehensive legislative oversight, is required to ensure parliamentary (political) support of the overall budget policy and the medium-term framework. Fourth, compliance of actual expenditures with the approved budget during the fiscal year is of essential importance for the credibility of the budget process. Table 3 summarizes these components.

The first and second elements are captured during phase 1. The existence of a macroeconomic and fiscal framework for forecasting is evaluated along the methodology on which the forecasts are based and along the detail of the projections. The highest score is obtained if a macroeconomic model based on clear assumptions regularly produces detailed projections. The medium term framework is evaluated by two criteria assessing the scope of multiannual plans at the aggregate and sectoral level and the existence of sectoral strategies and objectives. Ideally, there should be expenditure plans at the ministry or line level covering more than three years (the minimum period for an MTEF) and strategic objectives (including the expected output) should be formulated for each sector and activity. 
The third element is assessed according to the scope of the legislature's approval of the budget and the legislature's capacity to evaluate the budget during the second phase. Ideally, the legislature should debate the overall budget policy prior to or after the introduction of the executive's budget proposal. Thereby the capacity of the legislature to comprehend and analyze the proposal plays an essential role. The analysis should be conducted by topic or sector. If possible, research bureaux or specialized units of experts should be established for this purpose. ${ }^{21}$ Given the limited capacity of parliaments in many African countries, the second best score is awarded for the formation of parliamentary working groups according to expertise which are provided with relvant training. ${ }^{22}$

Finally, the fourth element is accounted for in phase 3 by two criteria measuring the flexibility to transfer funds between budgetary periods and units. Whereas the transfer of funds between periods should be forbidden to avoid opacity and thus incredibility of the budget allocations, the reallocation of funds between programs and administrative units may be allowed to provide some flexibility in case of external shocks. The reallocation of funds should however be subject to the approval of the legislature or the central budget authority (ideally both).

Table 3: Sustainability and Credibility Criteria

\begin{tabular}{|c|c|c|}
\hline BUDGET PHASE & CRITERIA & SOURCES \\
\hline Phase 1 & $\begin{array}{ll}\text { - } & \text { Multiannual Expenditure } \\
& \text { Plans } \\
\text { - } & \text { Macro-/ Fiscal Framework } \\
\text { - } & \text { Sectoral Framework }\end{array}$ & $\begin{array}{ll} & \text { PEFA, OECD, ROSC, IBP, } \\
& \text { IMF/ IBP Q's } \\
\text { - } & \text { IBP, ROSCs, IMF/ IBP Q's } \\
\text { - } & \text { IBP, OECD, IMF/ IBP Q's }\end{array}$ \\
\hline Phase 2 & $\begin{array}{ll}\text { - } & \text { Scope of Legislative Approval } \\
\text { - } & \text { Legislative Capacity } \\
\end{array}$ & $\begin{array}{ll}\text { - } & \text { PEFA, OECD, IMF/ IBP Q's } \\
\text { - } & \text { OECD, PEFA, IMF/ IBP Q's } \\
\end{array}$ \\
\hline Phase 3 & $\begin{array}{ll}\text { - } & \text { Inter-period Transferability of } \\
& \text { Funds } \\
\text { - } & \text { Reallocation of Funds } \\
\text { between Programs and Units }\end{array}$ & $\begin{array}{l}\text { - } \mathrm{OECD}, \mathrm{IMF} / \mathrm{IBP} \text { Q's } \\
\text { - } \mathrm{OECD}, \mathrm{IBP}, \mathrm{NL}, \mathrm{IMF} / \mathrm{IBP} \\
\text { Q's }\end{array}$ \\
\hline
\end{tabular}

21 The 2008 CABRI Report on Budget Practices and Procedures in Africa reports that several African countries have or are planning to set up legislative budget offices.

22 The 2008 CABRI Report on Budget Practices and Procedures in Africa shows that "African legislatures have, on average, less institutional capacity for financial scrutiny than their counterparts in the OECD". 


\section{Comprehensiveness}

Comprehensiveness ensures that all elements of expenditure are accounted for and subject to budgetary rules and procedures. A comprehensive budget helps to reduce malpractices such as hidden and escapist budgeting. This paper argues that there are two relevant dimensions of comprehensiveness in the budget process. The first dimension is the comprehensiveness of the coverage of the actual budget documents. The second dimension is the comprehensiveness of legislative approval of the annual budget. The legislature should receive and discuss detailed information on the components of the budget within the framework of overall budgetary objectives. This helps to hinder budgetary malpractices, such as hidden or unrealistic budgeting. The index accounts for comprehensiveness at the negotiation and planning- and at the legislative approval phase (as summarized in Table 4). If the first two phases comply with both dimensions of comprehensiveness, the implementation of the budget will necessarily also be comprehensive.

The first dimension is captured by four criteria during the first phase of the budget process. The first criterion punishes the existence of dual budgeting, i.e. the existence of two separate budgets for recurrent costs and investment, a frequent practice in developing countries that greatly facilitates hidden budgeting. The second criterion assesses the size of off-budget items and awards the highest score if these items sum up to less than four percent of the overall expenditure in the central government budget. Note that this is of particular importance in Africa, where extra-budgetary expenditures tend to be large. ${ }^{23}$ The third and fourth criteria evaluate the extent to which aid and debt are included in the budget. These two criteria are especially relevant for African countries where external aid and debt flows amount to substantial parts of the available funds and should therefore be included in the budgetary planning. ${ }^{24}$ However, in many cases the budget only includes direct budget support and excludes all project aid.

\footnotetext{
23 For example, the 2007 PEFA Report on Ethiopia stated that extra-budgetary expenditures represented more than ten percent of total expenditures between 2002 and 2005.

24 Consider, for example, Niger and Madagascar, where aid amounted to over 100 percent of government revenue in 2007.
} 
For the second dimension the index assesses the sequencing of the vote on the budget and the depth of the information contained in the budget documents presented to the legislature during phase 2. The legislature should first vote on the entire budget and then on individual spending items. The idea behind the top-down approach is that, once the overall size of the budget is approved, parliamentary groups cannot be tempted to promote additional spending that benefits their own narrow constituencies at the expense of overall expenditure and the general public. ${ }^{25}$ Finally, the legislature should hold extensive hearings on the budgets of administrative units during which testimony from the executive can be heard. The legislature should also be able to vote on the budgets of individual units.

Table 4: Comprehensiveness Criteria

\begin{tabular}{|c|c|c|}
\hline BUDGET PHASE & CRITERIA & SOURCES \\
\hline Phase 1 & $\begin{array}{ll}\text { - } & \text { Dual Budgeting } \\
\text { - } & \text { Size of Off-Budget Items } \\
\text { - } & \text { Inclusion of Aid } \\
\text { - } & \text { Inclusion of Debt }\end{array}$ & $\begin{array}{ll}\text { - } & \text { OECD, ROSC, IMF/ IBP Q's } \\
\text { - } & \text { OECD, PEFA, IMF/ IBP Q's } \\
\text { - } & \text { OECD, PEFA, IBP, IMF/ IBP Q's } \\
\text { - } & \text { OECD, PEFA, IBP, IMF/ IBP Q's }\end{array}$ \\
\hline Phase 2 & $\begin{array}{ll} & \text { Voting Sequence } \\
\text { - } & \text { Hearing/ Votes on Individual Budgets }\end{array}$ & $\begin{array}{ll}- & \text { OECD, NL, IMF/ IBP Q's } \\
\text { - } & \text { OECD, IBP, PEFA, IMF/ IBP Q's }\end{array}$ \\
\hline
\end{tabular}

\section{E. Transparency}

A transparent budget process provides the public with all relevant information in a timely and systematic manner. This should include complete information on policy objectives, the formulation and the implementation of these objectives, as well as the differences between the intended and the realized outcomes. Transparency throughout the entire budget process prevents hidden budgeting and corruption. Alt and Lassen (2003) develop an index measuring the transparency of budget processes in 19 OECD countries, and find that fiscal transparency leads to lower public debt and deficits. Hameed (2005) develops an index of fiscal transparency based on IMF and World Bank Reports of the Observance of Standards and Codes (ROSC). The overall index consists of four sub-indices measuring the level of transparency in data assurance, medium-term budgeting, budget execution, and fiscal risks.

25 See Ljungman (2009) for a discussion of top-down voting procedures in parliament. 
He shows that, for a broad range of countries, more transparency is associated with better fiscal discipline.

I measure transparency in all three budgetary phases. During phase 1, the index evaluates transparency along four criteria. First, the clarity of the roles and responsibilities during the first phase is measured. The legal framework should clearly identify all key aspects of financial management at the sectoral and regional level. Second, the draft budget should be published entirely or in great parts, so that the parliamentary discussion about this draft can be followed and understood by the general public. Third, macroeconomic forecasts and assumptions should be made publicly available and should be discussed in the greatest possible detail. This helps to understand if the budget proposal is based upon realistic assumptions. Finally, and for the same reason, information on macroeconomic risks should be published by the central budget authority.

During the second phase, it is important that the hearings on the overall budget policy and the individual budget items are made public. If they are not open to the public they should be either broadcast live or, alternatively, detailed reports should be published. This allows the public to monitor the legislature's exercise of control over the budget.

During phase 3, transparency is evaluated according to the publication of reports and performance targets. The perfect score is achieved if in-year reports covering all expenditures are published at least every quarter; a detailed year-end report explains the differences between the enacted and actual expenditures at the level of sectors, units, and programs; and finally if sectoral performance targets are made available to the public. Together the three criteria capture the ability of the general public to observe the size and progress of ongoing expenditures and to evaluate the outcome. Thereby the inclusion of performance targets is a particularly feasible and important requirement in most African countries where-at least in the social sectors-performance targets can be formulated in easily identifiable statistics, such as school enrollment, child death rates or HIV rates. The definition of quarterly publication of in-year reports as best practice differs markedly from the OECD's Best Practices which indicate that in-year reports should be published at least every month. Yet, 
as the CABRI Report on Budget Practices and Procedures in Africa (2008) rightly states, "less frequent reports based on more reliable data might be a better option when capacity to reduce high level data is limited".

Table 5: Transparency Criteria

\begin{tabular}{|c|c|c|}
\hline $\begin{array}{l}\text { BUDGET } \\
\text { PHASE }\end{array}$ & CRITERIA & SOURCES \\
\hline Phase 1 & $\begin{array}{ll}\text { - } & \text { Clarity of Roles and Responsibilities } \\
\text { - } & \text { Publication of Draft Budget } \\
\text { - } & \text { Publication of Macroeconomic Forecasts } \\
& \text { and Assumptions } \\
\text { - } & \text { Information on Macroeconomic Risk }\end{array}$ & $\begin{array}{ll}\text { - } & \text { OECD, ROSC, NL, IMF/ IBP Q's, } \\
\text { - } & \text { OECD, IBP, IMF/ IBP Q's } \\
\text { - } & \text { OECD,IBP ROSC, IMF/IBP Q's }\end{array}$ \\
\hline Phase 2 & $\begin{array}{l}\text { - } \quad \text { Public Hearings on Overall Budget Policy } \\
\text { - } \quad \text { Public Hearings on Individual Budgets }\end{array}$ & $\begin{array}{ll}\text { - } & \text { IBP, } \mathrm{ROSC}, \mathrm{IMF} / \mathrm{IBP} \text { Q's } \\
\text { - } & \mathrm{IBP}, \mathrm{ROSC}, \mathrm{IMF} / \mathrm{IBP} \text { Q's }\end{array}$ \\
\hline Phase 3 & $\begin{array}{ll}\text { - } & \text { Publication of In-Year Reports } \\
\text { - } & \text { Detail of Year-End Reports } \\
\text { - } & \text { Publication of Performance Targets }\end{array}$ & $\begin{array}{ll}\text { - } & \text { OECD, IBP, PEFA, ROSC, IMF/ IBP } \\
\text { - } & \text { IBP, PEFA, ROSC, IMF/IBP Q's } \\
\text { - } & \text { OECD, IBP, IMF/ IBP Q's }\end{array}$ \\
\hline
\end{tabular}

\section{DATA SOURCES}

In recent years, several attempts have been made to systematically measure the quality of BI in developing countries. In 1998, the IMF Board adopted the Code of Good Practices and Fiscal Transparency involving standards and codes on the budget process including the clarity of roles and responsibility; public availability of information; open budget preparation, execution and reporting; and assurances of integrity. Following this, the World Bank and the IMF have published Reports on the Observance of Standards and Codes (ROSCs) for 86 developed and developing countries including 28 African countries. Since 2004 the Public Expenditure and Financial Accountability (PEFA) Program, a joint project by the World Bank, the European Community, DFID, SECO, the Royal Norwegian Ministry of Foreign Affairs, the French Ministry of Foreign Affairs, and the IMF, conducts assessments and publishes reports covering a broad range of PFM performance indicators. Until 2009, 66 (mostly low- and middle-income) countries had been assessed based on the PFM Performance Measurement framework. Assessment reports for 22 African countries are publicly available. The OECD International Budget Practices and Procedures Database contains the results of surveys on national budgeting and financial management practices for 
the 30 OECD member countries and 67 non-members from Africa (26 countries), the Middle East, Eastern Europe, Asia, Latin America and the Caribbean. The International Budget Partnership, part of the Washington-based NGO Center on Budget and Policy Priorities, publishes the IBP Open Budget Index. The index provides extensive data and rankings on the level of transparency of the budget process in 85 developed and developing countries based on surveys conducted by local civil society partners. It includes 25 African countries.

For the construction of my index I rely on different sources for different criteria thereby taking advantage of the specific strengths of each of the above databases. I rely on PEFA reports for criteria related to budgetary practices and performance. Information on legal regulations and fiscal and procedural rules is mostly obtained from the information contained in the OECD database. The criteria on transparency are based on the IBP Open Budget Index surveys. ROSCs are used together with additional surveys sent out to IMF and IBP country teams to fill the gaps in my dataset. For some of the criteria, missing information could be found in the national legislation. I extract the relevant information from the reports, databases, and questionnaires and score this information as described in Table A-I 1 in the appendix. It should be emphasized that all the sources used for the construction of the index contain descriptions and surveys based on which (not based on the scores contained in the datasets) I construct the index scores. The fact that the criteria and associated questions are defined very specifically (and designed in a way that that if an OECD or IBP survey exists for the country the information can be extracted from the survey) leaves very little room for subjective interpretation. Consequently, it should not be a problem if information for the same question is taken from different sources for different countries. This way, the index can be compiled for 46 African countries. Somalia, Mauritania, Western Sahara, Guinea, Guinea Bissau, and Eritrea were not included because of the political situation in the countries. No information was available for Djibouti and the Comoros. 


\section{AGGREGATION OF THE INDEX}

I rely on three different methods for the aggregation of the index: equal weights, principal component analysis (PCA) and geometric aggregation with the weights derived from PCA. This allows for robustness checks. For the aggregation with equal weights I define five subindices along the five categories of the index. Each category is attributed a maximum score of one and each of the variables contained in the category is given equal weight. Missing values are excluded and the weights changed accordingly within the sub-indices of the respective countries. This yields the following specification for the centralization sub-index:

$I_{c}^{C e n t}=\sum_{i=1}^{2} v_{i}^{P N}{ }_{c} * w_{P N}+\sum_{i=1}^{2} v_{i c}^{A} * w_{A}+v_{c}^{I} * w_{I}$, where $I_{c}^{\text {Cent }}$ is the centralization sub-index for country $c, v$ is the component variable, $w$ is the weighting assigned to each variable within the three phases. $P N$ is the planning and negotiation phase (phase 1), $A$ is the approval phase (phase 2), and $I$ is the implementation phase (phase 3 ). The other four sub-indices are defined accordingly. The five sub-indices are then aggregated into an overall index. All of them are given equal weights. Finally, the overall index is scaled to range between zero and one. Table 6 below depicts the resulting scores. As shown in Figure 1, most countries obtain scores between 0.4 and 0.6. The scores obtained under PCA and geometric aggregation are depicted in Appendix II. ${ }^{26}$

26 For aggregation with PCA a principal component analysis with eigenvalues is run for each of the five sub-indices using stata. The results are then used to identify the number of components to be retained. Follwing standars practice, components contributing individually to the overall variance by more than ten percent and cumulatively by more than 60 percent and associated with eigenvalues equal to or larger than one are kept. Subsequently, the retained components are rotated using a varimax rotation. The weights for the individual variables of the sub-indices are obtained by constructing intermediate composites using squared factor loadings scaled to unity sum, and aggregating the intermediate composites by assigning a weight to each one of them equal to the proportion of the explained variance in the data set. The individual weight for each variable is the largest value of the squared factor loading scaled to unity sum multiplied by the proportion of the explained variance of the factor again scaled to unity. See OECD (2008 a) for a detailed explanation of this procedure. For the geometric aggregation I use the weights derived under PCA but aggregate the sub-components under each of the five indices as a product instead of a sum. . Each sub-index can thus be written as: $C I_{c}=\prod_{q=1}^{Q} x_{q, c}^{w_{q}}$, where $\mathrm{q}$ is the sub-component and $w_{q}$ is the weight associated with the subcomponent. 
Figure 1: Histogram on Index Values

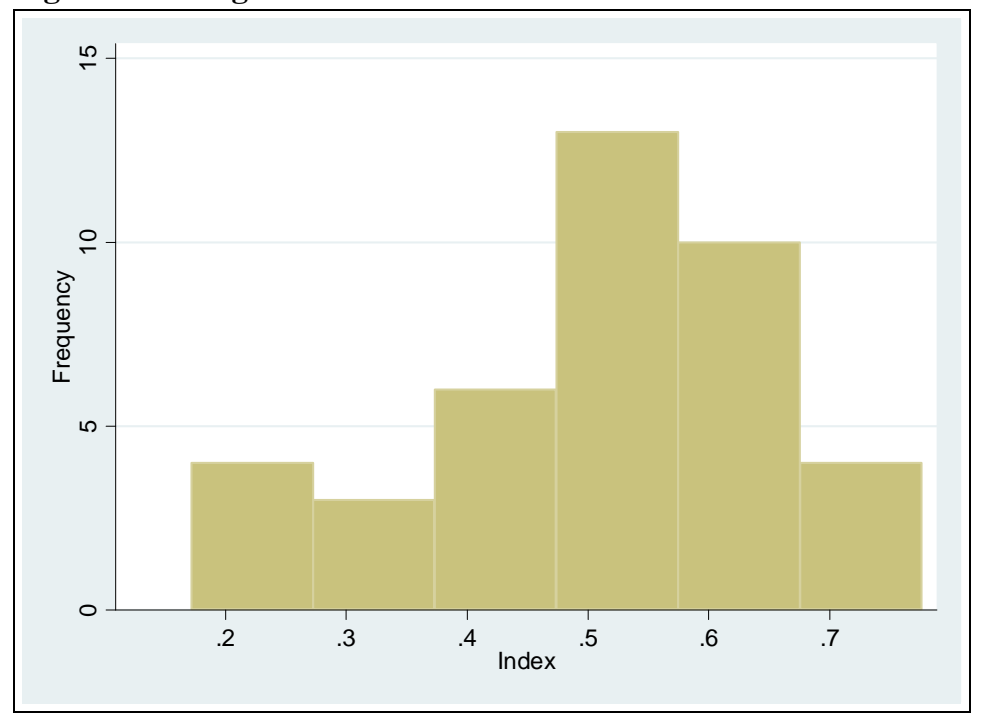

The ten countries that score worst under the aggregation with equal weights include Sudan, with the lowest score by far, the Central African Republic (CAR), the Democratic Republic of Congo, Equatorial Guinea, the Gambia, Algeria, Cameroon, Sao Tome \& Principe, the Seychelles, and Burundi. The countries all lose most of their points under the sustainability, comprehensiveness, and transparency categories. Interestingly, out of these ten countries four have military regimes (Sudan, CAR, Equatorial Guinea, and Gambia). The top ten performers (in declining order) include Namibia, Cape Verde, Togo, South Africa, Tanzania, Sierra Leone, Kenya, Niger, Tunisia, and Madagascar. While this group includes the continent's most stable and democratic countries (Namibia, Cape Verde, and South Africa), the high scores of Togo and Niger are surprising. The score of Togo could be explained by the recent reforms, but Niger should be expected to receive a very low score in spite of President Tandja's democratic reforms. Furthermore, it is surprising that Botswana is not among the top ten performers.

The disaggregated scores are shown in Table 6 and shed some light on the surprising scores of Botswana and Niger. Botswana scores very low under sustainability and credibility and under comprehensiveness. The low score under sustainability and credibility derives (amongst others) from Botswana's relatively low score under the medium-term planning criteria, and the transferability of funds from one year to the next. The relatively low score 
under comprehensiveness can be explained by the separation in the preparation of the recurrent expenditure- and capital investment budget (although the final document unifies both budgets), and the fact that parliament does not vote on the overall size of the budget before voting on specific appropriations. Niger's relatively high score is driven by aboveaverage performance under centralization and under transparency. The Minister of Finance is very powerful in the budget process and the budget process is very transparent including the publication of all key documents and public hearings on the budget. Considering the aggregation by budgetary phases (depicted in the appendix), it becomes evident that Botswana looses most points under phase 2 whereas Niger gains most points under phase 1. Overall, the scores of Botswana and Niger clearly demonstrate the weaknesses of measuring the performance of highly diverse countries with the same relatively narrow criteria-the main disadvantage of almost any index. Furthermore, both scores underline the weakness of granting equal weights to each subcomponent-a method of aggregation under which countries with very different performances can gain identical scores. Two alternative methods of aggregation (PCA and geometric aggregation) are presented in this paper. Another alternative would have been to assign specific weights according to the relative importance to the different sub-components—-something that has not been done in this paper as this methodology is always extremely subjective. 
Table 6: Index Values with Equal Weights

\begin{tabular}{|c|c|c|c|c|c|c|}
\hline COUNTRY & $\begin{array}{l}\text { CENTRA- } \\
\text { LIZATION }\end{array}$ & $\begin{array}{l}\text { RULES \& } \\
\text { CONTROLS }\end{array}$ & $\begin{array}{l}\text { SUSTAINA- } \\
\text { BILITY }\end{array}$ & $\begin{array}{l}\text { COMPREHEN- } \\
\text { SIVENESS } \\
\end{array}$ & $\begin{array}{l}\text { TRANSPA- } \\
\text { RENCY }\end{array}$ & OVERALL \\
\hline Algeria & 0.500 & 0.264 & 0.194 & 0.313 & 0.313 & 0.317 \\
\hline Angola & 0.667 & 0.486 & 0.403 & 0.688 & 0.750 & 0.599 \\
\hline Benin & 0.750 & 0.653 & 0.431 & 0.313 & 0.653 & 0.560 \\
\hline Botswana & 0.500 & 0.569 & 0.278 & 0.313 & 0.424 & 0.417 \\
\hline $\begin{array}{l}\text { Burkina } \\
\text { Faso }\end{array}$ & 0.583 & 0.667 & 0.431 & 0.219 & 0.292 & 0.438 \\
\hline Burundi & 0.750 & 0.444 & 0.486 & 0.094 & 0.208 & 0.397 \\
\hline Cameroon & 0.250 & 0.583 & 0.417 & 0.250 & 0.125 & 0.325 \\
\hline Cape Verde & 0.917 & 0.583 & 0.708 & 0.813 & 0.542 & 0.712 \\
\hline CAR & 0.333 & 0.167 & 0.250 & 0.250 & 0.063 & 0.213 \\
\hline Chad & 0.708 & 0.347 & 0.403 & 0.469 & 0.389 & 0.463 \\
\hline Congo, DR & 0.208 & 0.236 & 0.278 & 0.313 & 0.167 & 0.240 \\
\hline Congo, Rep. & 0.417 & 0.722 & 0.500 & 0.500 & 0.597 & 0.547 \\
\hline CDI & 0.375 & 0.417 & 0.639 & 0.594 & 0.083 & 0.422 \\
\hline Egypt & 0.583 & 0.556 & 0.611 & 0.250 & 0.382 & 0.476 \\
\hline Equ. Guinea & 0.625 & 0.375 & 0.194 & 0.000 & 0.063 & 0.251 \\
\hline Ethiopia & 0.625 & 0.500 & 0.278 & 0.688 & 0.201 & 0.458 \\
\hline Gabon & 0.708 & 0.431 & 0.583 & 0.688 & 0.583 & 0.599 \\
\hline Gambia, The & 0.500 & 0.222 & 0.319 & 0.188 & 0.104 & 0.267 \\
\hline Ghana & 0.792 & 0.542 & 0.569 & 0.719 & 0.250 & 0.574 \\
\hline Kenya & 0.500 & 0.764 & 0.778 & 0.531 & 0.632 & 0.641 \\
\hline Lesotho & 0.792 & 0.333 & 0.569 & 0.406 & 0.479 & 0.516 \\
\hline Liberia & 0.625 & 0.708 & 0.111 & 0.500 & 0.125 & 0.414 \\
\hline Libya & 0.167 & 0.375 & 0.444 & 0.563 & 0.528 & 0.415 \\
\hline Madagascar & 0.750 & 0.542 & 0.597 & 0.844 & 0.396 & 0.626 \\
\hline Malawi & 0.333 & 0.556 & 0.708 & 0.250 & 0.556 & 0.481 \\
\hline Mali & 0.708 & 0.694 & 0.528 & 0.531 & 0.646 & 0.622 \\
\hline Mauritius & 0.667 & 0.569 & 0.681 & 0.469 & 0.326 & 0.542 \\
\hline Morocco & 0.458 & 0.597 & 0.722 & 0.406 & 0.562 & 0.549 \\
\hline Mozambique & 0.375 & 0.736 & 0.472 & 0.813 & 0.354 & 0.550 \\
\hline Namibia & 0.917 & 0.792 & 0.819 & 0.781 & 0.569 & 0.776 \\
\hline Niger & 0.750 & 0.569 & 0.556 & 0.594 & 0.687 & 0.631 \\
\hline Nigeria & 0.667 & 0.639 & 0.764 & 0.250 & 0.563 & 0.576 \\
\hline Rwanda & 0.625 & 0.778 & 0.611 & 0.594 & 0.236 & 0.569 \\
\hline STP & 0.625 & 0.347 & 0.250 & 0.156 & 0.250 & 0.326 \\
\hline Senegal & 0.792 & 0.542 & 0.458 & 0.719 & 0.319 & 0.566 \\
\hline Seychelles & 0.750 & 0.472 & 0.069 & 0.125 & 0.431 & 0.369 \\
\hline Sierra Leone & 0.583 & 0.736 & 0.611 & 0.594 & 0.722 & 0.649 \\
\hline South Africa & 0.583 & 0.486 & 0.861 & 0.563 & 0.896 & 0.678 \\
\hline Sudan & 0.042 & 0.208 & 0.278 & 0.250 & 0.083 & 0.172 \\
\hline Swaziland & 0.625 & 0.403 & 0.403 & 0.344 & 0.396 & 0.434 \\
\hline Tanzania & 0.625 & 0.639 & 0.500 & 0.781 & 0.729 & 0.655 \\
\hline Togo & 0.708 & 0.556 & 0.653 & 0.969 & 0.514 & 0.680 \\
\hline Tunisia & 0.792 & 0.764 & 0.583 & 0.281 & 0.715 & 0.627 \\
\hline Uganda & 0.250 & 0.264 & 0.722 & 0.844 & 0.729 & 0.562 \\
\hline Zambia & 0.667 & 0.361 & 0.514 & 0.500 & 0.778 & 0.564 \\
\hline Zimbabwe & 0.667 & 0.361 & 0.556 & 0.188 & 0.215 & 0.397 \\
\hline
\end{tabular}




\section{EMPIRICAL ANALYSIS}

\section{A. Spearman Rank Correlation}

It is interesting to consider the correlations between the different sub-components of the index. Table 7 shows that while all categories have positive correlation coefficients with all of the other categories, only transparency is strongly and significantly correlated with all of the other categories. The weakest correlation seems to exist between centralization and sustainability.

Table 7: Spearman Rank Correlations between Index Categories

\begin{tabular}{|c|c|c|c|c|c|}
\hline & CENTRALIZATION & $\begin{array}{l}\text { RULES \& } \\
\text { CONTROLS }\end{array}$ & " SUSTAINABILITY & $\begin{array}{l}\text { COMPREHEN- } \\
\text { SIVENESS }\end{array}$ & TRANSPARENCY \\
\hline Centralization & 1.000 & & & & \\
\hline $\begin{array}{ll}\text { Rules } & \& \\
\text { Controls } & \end{array}$ & $\begin{array}{l}0.233 \\
(0.148)\end{array}$ & 1.000 & & & \\
\hline Sustainability & $\begin{array}{l}0.178 \\
(0.273)\end{array}$ & $\begin{array}{l}0.447 * * * \\
(0.004)\end{array}$ & 1.000 & & \\
\hline $\begin{array}{l}\text { Comprehen- } \\
\text { Siveness }\end{array}$ & $\begin{array}{l}0.317 * * \\
(0.046)\end{array}$ & $\begin{array}{l}0.233 \\
(0.148)\end{array}$ & $\begin{array}{l}0.358 * * \\
(0.023)\end{array}$ & 1.000 & \\
\hline Transparency & $\begin{array}{l}0.315 * * \\
(0.048)\end{array}$ & $\begin{array}{l}0.344 * * \\
(0.030)\end{array}$ & $\begin{array}{l}0.444 * * * \\
(0.004)\end{array}$ & $\begin{array}{l}0.291^{*} \\
(0.069)\end{array}$ & 1.000 \\
\hline
\end{tabular}

$P$-values in brackets; $* * * p<0.01, * * p<0.05, * p<0.1$

Next, I examine the correlation of BI with fiscal outcomes. I consider two different fiscal variables: public and publicly guaranteed external debt as ratio of GDP (ped); and the central government primary balance as ratio of GDP ( $c g p b)$. Data on the central government gross debt were not available for a substantial number of countries in our sample. It is therefore also impossible to consider the impact of BI on the government's overall budget balance, as the latter includes interest payments on the gross debt. All variables are averaged over 2003 to $2007 .{ }^{27}$ Data on public external debt were not available for Libya and Equatorial Guinea. For Zimbabwe, no reliable data on the central government primary balance was available. Standard tests on the remaining sample indicated the presence of outliers and in a first round of regression including the entire sample none of the explanatory variables was significant in

27 Since the BI index data could only be collected for contemporary (2006-2009) budget institutions, considering earlier years in the empirical analysis would not be meaningful. Data for 2008 was not included due to the economic shocks. For the same reason, 2001 should not be included in the analysis. Thus, in order to allow for a one year time-lag, I take averages between 2003 and 2007. 
either regression. To eliminiate the effect of outliers I therefore excluded observations which are more than two standard deviations away from the mean in debt or the primary balance. ${ }^{28}$

I follow von Hagen (1992) and Prakash and Cabezon (2008) in first performing nonparametric tests which do not require explicit specifications of the relationships. The Spearman rank correlation coefficients for the equal weights version of the overall index and sub-indices with the two fiscal variables are depicted in Table $8 .{ }^{29}$

Table 8: Spearman Rank Coefficients for Equal Weights Aggregation

\begin{tabular}{||l|l|l|l|l|l|l||}
\hline \hline & OVERALL & $\begin{array}{l}\text { CENTRALI } \\
\text { ZATION }\end{array}$ & $\begin{array}{l}\text { RULES \& } \\
\text { CONT } \\
\text { ROLS }\end{array}$ & $\begin{array}{l}\text { SUSTAINABI } \\
\text { LITY }\end{array}$ & $\begin{array}{l}\text { COMPREHENSI } \\
\text { VENESS }\end{array}$ & TRANSPARENCY \\
\hline PED & -0.221 & -0.246 & -0.248 & -0.2315 & 0.004 & -0.258 \\
& $(0.170)$ & $0.126)$ & $(0.123)$ & $(0.1507)$ & $(0.981)$ & $(0.108)$ \\
\hline CGPB & 0.005 & -0.030 & -0.087 & -0.0467 & -0.182 & $0.277 *$ \\
& $(0.975)$ & $(0.853)$ & $(0.593)$ & $(0.7746)$ & $(0.262)$ & $(0.083)$ \\
\hline
\end{tabular}

P-values in brackets; $* * * p<0.01, * * p<0.05, * p<0.1$

Overall, it seems that budgetary institutions are negatively correlated with external debt, thus suggesting that countries with better BI have lower levels of public external debt. This correlation seems to be weakest, least significant (and even positive) for the comprehensiveness sub-index. The correlation with the primary balance is less clear. The signs change between the different sub-indices and the correlation is mostly highly insignificant. Only the transparency sub-index is significantly (positively) correlated with the budget balance. ${ }^{30}$ However, the Spearman rank correlations might not be very informative as the countries included in my sample are very heterogeneous and their fiscal outcomes are

28 Three countries were excluded as a result: Sao Tome and Principe was the only outlier in the primary balance with a balance about seven times as large as the average in the sample. Once Sao Tome and Principe was excluded, the results for the primary balance improved. Liberia and Burundi were excluded as clear outliers in public external debt with values of over three times the sample average. For the sake of clarity I studied the same sample in both regressions.

29 The Spearman rank coefficient measures the correlation between the ranks of the variables in the sample thereby excluding the scale effects but keeping the order of the relation observed in the ranks.

30 The results are similar for the PCA-aggregated version of the index. 
influenced by a number of important factors that may affect the impact of institutional quality. I therefore turn to an econometric analysis.

\section{B. Econometric Analysis with OLS}

The objective is to analyze the effect of budgetary quality on the two fiscal outcomes, as expressed in the following model:

$y=\alpha_{0}+x \beta+\gamma q+\varepsilon$, where $y$ is the fiscal outcome, $x$ is a vector of exogenous explanatory variables, and $q$ is institutional quality.

The following explanatory variables are included in the regression analysis: the BI index (index), average economic growth (growth), the logarithm of initial GDP per capita measured in 2002 ( $g d p p c \_2002$ ) as indicator of the initial income level, the product of annual growth in net barter terms of trade and openness (the ratio of trade to GDP) (trade) as indicator of a country's dependency on trade, the average fractionalization index (fractionalization) to proxy unity and stability of the government, a dummy for the Highly Indebted Poor Countries Initiative debt relief completion point (hipcc), and a dummy for mineral and hydrocarbon rich countries (resources). A detailed description of all the variables included in the regression (including their sources) is provided in Appendix III. I run simple OLS regressions with robust estimates of the standard errors to adjust for heteroscedasticity. The regressions are first run without the BI index. Subsequently, the overall index is added. Finally, all the sub-indices are included individually and separately.

\section{External Debt}

Overall, as depicted in Table 9, external debt seems to be related most significantly to the initial GDP per capita. Countries with higher initial income borrow less abroad. The coefficients of the other explanatory variables-apart from the budget index-are not significant at the 90 percent level. ${ }^{31}$ As expected, HIPC debt relief is associated with lower

\footnotetext{
$31 \quad$ Note that trade is only marginally insignificant and significant for the specifications including the centralization sub-index.
} 
external debt. Resource-rich countries seem to enjoy more access to external funds than resource-poor countries (although not at a significant level) as resources can serve as collateral for loans. The coefficient of fractionalization is (surprisingly) negative and insignificant, suggesting that more ethnically, linguistically and religiously diverse societies tend to have lower external debts. ${ }^{32}$ The overall BI index is strongly, negatively and significantly correlated with public external debt. Countries with better budgetary institutions tend to have lower levels of external debt. More precisely, an improvement in the index by 0.1 points is associated with a reduction by six percent in public external debt.

This result differs from the Spearman rank analysis in which the correlation between public external debt and the BI index is not statistically significant. It appears that this difference is driven by the assumption of a linear relationship between debt and the index as the coefficient of the index is even significant when included alone on the right hand side and remains significant as the other control variables are included one by one. ${ }^{33}$ All individual sub-indices have negative coefficients but, if included individually and separately, only the coefficient associated with centralization is significant under both methods of aggregation. The same is found when all the subcategories are included individually and simultaneously in the regression: centralization has the only significant and by far the largest coefficient. However, when performing a Wald test, I cannot reject the null hypothesis of equality of the coefficients of all the categories. ${ }^{34}$ To test if the effect of centralization drives the significance of the BI index, I include both centralization and the overall index on the right hand side (depicted in the last column of Table 9). Indeed, the coefficient associated with the overall index is now insignificant and smaller. The coefficient associated with centralization is more significant and larger than the coefficient of the overall index. I can conclude that better budget institutions are associated with lower external debt and that the correlation between

\footnotetext{
32 A possible explanation may be that fractionalized countries are more prone to internal conflict and civil war and as a result of the associated risks foreign lenders may be less willing to provide funds.

33 These results are available upon request.

34 The results are available upon request. It should be emphasized however, that including all of the subcategories individually and at the same time may lead to serious multicollinearity problems because of the high correlation between the different subcomponents.
} 
centralization and debt is stronger than between the other categories and debt although this difference is not significant. 
Table 9: Public External Debt with Equal Weights Index

\begin{tabular}{|c|c|c|c|c|c|c|c|c|}
\hline & $\begin{array}{c}\text { WITHOUT } \\
\text { BI }\end{array}$ & " WITH BI & $\begin{array}{l}\text { CENTRA- } \\
\text { LIZATION }\end{array}$ & RULES & $\begin{array}{c}\text { SUSTAINA- } \\
\text { BILITY }\end{array}$ & $\begin{array}{c}\text { COMPREHEN- } \\
\text { SIVENESS }\end{array}$ & $\begin{array}{c}\text { TRANSPA- } \\
\text { RENCY }\end{array}$ & $\begin{array}{c}\text { WITH BI AND } \\
\text { CENTRA- } \\
\text { LIZATION }\end{array}$ \\
\hline VARIABLES & ped & ped & ped & ped & ped & ped & ped & ped \\
\hline \multirow[t]{2}{*}{ Growth } & -1.838 & -0.893 & -1.074 & -1.615 & -1.603 & -1.420 & -1.023 & -0.900 \\
\hline & $(1.557)$ & $(1.659)$ & $(1.510)$ & $(1.683)$ & (1.652) & $(1.749)$ & $(1.640)$ & $(1.564)$ \\
\hline \multirow[t]{2}{*}{ gdppc_2002 } & $-0.279 * * *$ & $-0.241 * * *$ & $-0.237 * * *$ & $-0.259 * * *$ & $-0.266 * * *$ & $-0.274 * * *$ & $-0.253 * * *$ & $-0.233 * * *$ \\
\hline & $(0.0679)$ & $(0.0649)$ & $(0.0651)$ & $(0.0728)$ & $(0.0635)$ & $(0.0652)$ & $(0.0679)$ & $(0.0663)$ \\
\hline \multirow[t]{2}{*}{ Trade } & 1.446 & 1.275 & 1.773 & 1.282 & 0.940 & 1.486 & 1.434 & 1.639 \\
\hline & $(1.229)$ & (1.093) & $(1.182)$ & $(1.238)$ & $(1.184)$ & $(1.167)$ & $(1.186)$ & $(1.100)$ \\
\hline \multirow[t]{2}{*}{ Resources } & 0.170 & 0.140 & 0.114 & 0.169 & 0.164 & 0.150 & 0.161 & 0.115 \\
\hline & $(0.151)$ & $(0.158)$ & $(0.154)$ & $(0.156)$ & $(0.152)$ & $(0.151)$ & $(0.159)$ & $(0.155)$ \\
\hline \multirow[t]{2}{*}{ Hipcc } & -0.118 & -0.0662 & -0.0481 & -0.0672 & -0.135 & -0.0988 & -0.106 & -0.0448 \\
\hline & $(0.104)$ & $(0.102)$ & $(0.106)$ & $(0.120)$ & $(0.102)$ & $(0.106)$ & $(0.100)$ & $(0.107)$ \\
\hline \multirow[t]{2}{*}{ Fractionalization } & -0.321 & -0.262 & -0.402 & -0.324 & -0.263 & -0.253 & -0.274 & -0.363 \\
\hline & $(0.255)$ & $(0.294)$ & $(0.284)$ & $(0.277)$ & $(0.272)$ & $(0.271)$ & $(0.287)$ & $(0.306)$ \\
\hline \multirow[t]{2}{*}{ Index } & & $-0.627 *$ & & & & & & -0.227 \\
\hline & & $(0.362)$ & & & & & & $(0.494)$ \\
\hline \multirow[t]{2}{*}{ Centralization } & & & $-0.555^{* *}$ & & & & & -0.433 \\
\hline & & & $(0.220)$ & & & & & $(0.294)$ \\
\hline \multirow[t]{2}{*}{ Rules } & & & & -0.242 & & & & \\
\hline & & & & $(0.377)$ & & & & \\
\hline \multirow[t]{2}{*}{ Sustainability } & & & & & -0.357 & & & \\
\hline & & & & & $(0.251)$ & & & \\
\hline \multirow[t]{2}{*}{ Comprehensiveness } & & & & & & -0.224 & & \\
\hline & & & & & & $(0.244)$ & & \\
\hline \multirow[t]{2}{*}{ Transparency } & & & & & & & -0.300 & \\
\hline & & & & & & & $(0.229)$ & \\
\hline \multirow[t]{2}{*}{ Constant } & $2.814 * * *$ & $2.766 * * *$ & $2.824 * * *$ & $2.770 * * *$ & $2.874 * * *$ & $2.827 * * *$ & $2.681 * * *$ & $2.804 * * *$ \\
\hline & $(0.627)$ & $(0.572)$ & $(0.584)$ & $(0.620)$ & $(0.588)$ & $(0.612)$ & $(0.612)$ & $(0.584)$ \\
\hline Observations & 40 & 40 & 40 & 40 & 40 & 40 & 40 & 40 \\
\hline R-squared & 0.392 & 0.452 & 0.472 & 0.403 & 0.424 & 0.412 & 0.427 & 0.476 \\
\hline
\end{tabular}

Robust standard errors in parentheses; $* * * p<0.01, * * p<0.05, * p<0.1$ 


\section{Central Government Primary Balance}

The central government primary budget balance corresponds to the overall budget balance excluding interest payments. As shown in Table 10, the primary budget balance is most strongly correlated with growth and the resource dummy. Countries with higher growth tend to have lower primary balances, thus suggesting that fast-growing countries tend to borrow against future income. Other things equal, resource-rich countries tend to have higher primary balances. The correlations with fractionalization is negative but insignificant and very small. Contrary to what I would expect, the correlation with initial GDP per capita is negative and highly insignificant. The coefficient of trade is significant and positive indicating that a greater reliance on trade may be beneficial for fiscal outcomes. A possible explanation for this phenomenon is that a greater reliance on trade leads to more economic volatility which may necessitate sound fiscal planning. The overall index is positively but insignificantly correlated with the budget balance. The coefficient however is more significant than the coefficient obtained in the Spearman rank correlation. This difference seems to be driven by the assumption of a linear relationship between the primary balance and the BI index and by the inclusion of the control variables. The coefficient of the index becomes more significant as more of the control variables are included but does not seem to be affected strongly by a particular variable. ${ }^{35}$ Apart from comprehensiveness (which has a highly insignificant and negative coefficient), all sub-indices have positive coefficients. However, only the coefficient associated with transparency is significant, suggesting that transparency is the aspect of budgetary quality that affects the budget balance most strongly. A country with a perfectly transparent budget has, ceteris paribus, a five percent higher budget balance than a country at the other end of my transparency index or, put differently, a 0.1 point improvement in the transparency index is associated with half a percent improvement in the budget balance.. ${ }^{36}$ Again, this finding is confirmed when all categories are included individually: transparency has the only significant and by far the largest coefficient. However, in the subsequent Wald test, the null hypothesis of equality of the

\footnotetext{
35 These results are available upon request.

36 The results for the PCA version of the index were very similar, as shown in appendix IV.
} 
coefficients of all the categories cannot be rejected. ${ }^{37}$ Finally, to investigate whether the correlation between the primary balance and the index is driven by the transparency category, I include the overall index and transparency simultaneously on the right hand side. As the last column of Table 10 shows, the positive correlation between the index and the budget balance seems to be driven almost entirely by transparency. The coefficient associated with the overall index is now negative and highly insignificant whereas the coefficient associated with transparency is positive and significant.

Overall, the correlation between the budget balance and BI seems to be significantly weaker than the correlation between external debt and BI. There is a straight-forward explanation for this phenomenon: while dependence on foreign creditors is almost always undesirable for trade-oriented economies that are already greatly affected by external shocks, a higher primary deficit may not always be bad. An economically underdeveloped country which expects high future growth (e.g. after the discovery of oil or minerals) might find it optimal to borrow against the future to let the population participate in the economic upswing at an early stage and to accelerate the development process. Yet, the deficit can be financed domestically and not through external debt. ${ }^{38}$ In this case, higher BI may very well be associated with higher deficits.

\footnotetext{
$37 \quad$ As for ped, the results are available upon request.

38 Unfortunately, this hypothesis cannot be tested as data for the overall government debt was not available for all countries.
} 
Table 10: Central Government Primary Balance with Equal Weights Index

\begin{tabular}{|c|c|c|c|c|c|c|c|c|}
\hline & $\begin{array}{c}\text { WITHOUT } \\
\text { BI }\end{array}$ & WITH BI & $\begin{array}{l}\text { CENTRA- } \\
\text { LIZATION }\end{array}$ & RULES & $\begin{array}{l}\text { SUSTAINA- } \\
\text { BILITY }\end{array}$ & $\begin{array}{l}\text { COMPREHEN- } \\
\text { SIVENESS }\end{array}$ & $\begin{array}{l}\text { TRANSPA- } \\
\text { RENCY }\end{array}$ & $\begin{array}{c}\text { WITH BI AND } \\
\text { TRANS-PARENCY }\end{array}$ \\
\hline VARIABLES & cgpb & cgpb & cgpb & cgpb & cgpb & cgpb & cgpb & cgpb \\
\hline \multirow[t]{2}{*}{ Growth } & $-0.455^{*}$ & $-0.510 *$ & $-0.472 *$ & $-0.473^{*}$ & $-0.468 *$ & $-0.444 *$ & $-0.590 * *$ & $-0.581 * *$ \\
\hline & $(0.226)$ & $(0.254)$ & $(0.241)$ & $(0.236)$ & $(0.239)$ & $(0.236)$ & $(0.258)$ & $(0.259)$ \\
\hline \multirow[t]{2}{*}{ gdppc_2002 } & -0.00232 & -0.00379 & -0.00287 & -0.00293 & -0.00321 & -0.00232 & -0.00617 & -0.00604 \\
\hline & $(0.00825)$ & $(0.00816)$ & $(0.00856)$ & $(0.00805)$ & $(0.00840)$ & $(0.00848)$ & $(0.00789)$ & $(0.00826)$ \\
\hline \multirow[t]{2}{*}{ Trade } & $0.222 *$ & $0.238 *$ & $0.218 *$ & $0.244 *$ & $0.247 *$ & $0.222 *$ & $0.228 *$ & $0.210 *$ \\
\hline & $(0.113)$ & $(0.121)$ & $(0.114)$ & $(0.129)$ & $(0.129)$ & $(0.115)$ & $(0.119)$ & $(0.123)$ \\
\hline \multirow[t]{2}{*}{ Resources } & $0.0414 * *$ & $0.0431 * *$ & $0.0426^{* *}$ & $0.0413 * *$ & $0.0418^{* *}$ & $0.0409 * *$ & $0.0428 * * *$ & $0.0414 * *$ \\
\hline & $(0.0164)$ & $(0.0162)$ & $(0.0168)$ & $(0.0166)$ & $(0.0165)$ & $(0.0169)$ & $(0.0152)$ & $(0.0152)$ \\
\hline \multirow[t]{2}{*}{ Fractionalization } & -0.00773 & -0.0101 & -0.00538 & -0.00605 & -0.0111 & -0.00605 & -0.0149 & -0.0152 \\
\hline & $(0.0320)$ & $(0.0328)$ & $(0.0326)$ & $(0.0348)$ & $(0.0334)$ & $(0.0338)$ & $(0.0331)$ & $(0.0334)$ \\
\hline \multirow[t]{2}{*}{ Index } & & 0.0369 & & & & & & -0.0469 \\
\hline & & $(0.0449)$ & & & & & & $(0.0648)$ \\
\hline \multirow[t]{2}{*}{ Centralization } & & & 0.0123 & & & & & \\
\hline & & & $(0.0402)$ & & & & & \\
\hline \multirow[t]{2}{*}{ Rules } & & & & 0.0199 & & & & \\
\hline & & & & $(0.0373)$ & & & & \\
\hline \multirow[t]{2}{*}{ Sustainability } & & & & & 0.0187 & & & \\
\hline & & & & & $(0.0313)$ & & & \\
\hline \multirow[t]{2}{*}{ Comprehensiveness } & & & & & & -0.00615 & & \\
\hline & & & & & & $(0.0275)$ & & \\
\hline \multirow[t]{2}{*}{ Transparency } & & & & & & & $0.0497 *$ & $0.0724^{*}$ \\
\hline & & & & & & & $(0.0264)$ & $(0.0416)$ \\
\hline \multirow[t]{2}{*}{ Constant } & 0.0526 & 0.0481 & 0.0486 & 0.0462 & 0.0515 & 0.0542 & 0.0698 & 0.0834 \\
\hline & $(0.0808)$ & $(0.0785)$ & $(0.0797)$ & $(0.0846)$ & $(0.0811)$ & $(0.0828)$ & $(0.0766)$ & $(0.0813)$ \\
\hline Observations & 40 & 40 & 40 & 40 & 40 & 40 & 40 & 40 \\
\hline R-squared & 0.376 & 0.389 & 0.378 & 0.381 & 0.381 & 0.377 & 0.433 & 0.442 \\
\hline
\end{tabular}

Robust standard errors in parentheses; $* * * p<0.01, * * p<0.05, * p<0.1$ 


\section{Caveats and Robustness Checks}

As has been emphasized before, one of the major advantages of the index presented in this paper is its two-dimensionality. This means that the index can be aggregated either across categories or across budgetary phases. In the analysis presented above I chose to aggregate the index across categories. To test if the results change with the method of aggregation, I repeated the same regressions for the version of the index which was aggregated (with equal weights) across phases. ${ }^{39}$ As presented, in appendix V , the results are very similar: almost the same group of countries performs best (although Mali replaces Madagascar under the ten top-performers) and almost the same group of countries performs worst (only Burundi is replaced by Libya) under the index aggregated across phases. Furthermore, Spearman rank correlations suggest that the two overall indices have a correlation coefficient of 0.99 at a significance level of over 99 percent. ${ }^{40}$ I then repeated the regressions for debt and the budget balance with the new version of the index and the individual phase-indices. For the debt regressions, the results do not change significantly with the overall phases index. Interestingly, however, while all budgetary phases have a negative coefficient, only phase 1 and phase 3 have a statistically significant impact. The effect of the parliamentary approval phase is not significant at the 90 percent significance level. This may suggest that the planning and execution phases play a greater role in committing governments to lower debt than the parliamentary approval phase. However when including the three stages simultaneously, the Wald test shows that the null hypothesis of equal coefficients cannot be rejected. For the budget balance regressions, the results are similar as well. The overall index has a positive but statistically insignificant index. Phases 1 and 2 have positive although statistically insignificant coefficients. Phase 3 has a very small and negative coefficient, which is highly insignificant. Again, the differences between the three coefficients are, however, not significant.

39 For example, the sub-index for phase 1 is constructed as follows:

$I_{p}^{1}=\sum_{i=1}^{2} v_{i}^{c e n t} * w_{c e n t}+\sum_{i=1}^{2} v_{i}^{r c} * w_{r c}+\sum_{i=1}^{3} v_{i}^{s c} * w_{s c}+\sum_{i=1}^{4} v_{i}^{\text {comp } *} w_{\text {comp }}+\sum_{i=1}^{4} v_{i}^{\text {trans }} * w_{\text {trans }}$

where $I_{p}^{1}$ is the sub-index for the first phase and can take a maximum value of one. 
The most obvious shortcoming of the econometric analysis is the lack of a time dimension in the dataset on budget institutions. I was only able to collect the most recently available information on budget institutions in African countries including data between 2006 and 2009. This information is largely representative for the period between 2003 and 2009 as most of the reforms concerning the restructuring of public financial management were introduced prior to 2003. Naturally, it would be far more interesting to run panel regressions. With panel data it would also be possible to investigate to what extent sound budgetary institutions promote counter-cyclical fiscal behaviour, an analysis that would be far more revealing than the mere interpretation of conditional correlations with debt and deficit levels. As this study has become part of an IMF research project, I hope that the index will be updated regularly and it will be possible to construct time-series data on African budget institutions.

Another common point of criticism is that the initial debt level is not included as a control variable in the regressions depicted in Table 9. The reason for this omission is quite simple: the initial (2002) level of publically guaranteed external debt as ratio to GDP is very strongly correlated with the BI index (about as strongly as contemporary debt) because BI have not changed much over the past years in the majority of the countries included in my sample. ${ }^{41}$ Therefore the inclusion of the initial debt on the right-hand side creates serious multicollinearity problems and the coefficients of the index becomes very small and insignificant. However, if my index adequately captures BI over the past years, it should explain the change in public external debt over the longer-run. It has been mentioned above that in the late 1980's public external debt was extremely high in almost any African country. In the country sample included in the regression analysis the average external debt to GDP ratio was about 71 percent in 1990. Between the mid-1990's and the early 2000 this average was reduced to 30 percent. Yet the average hides large differences in the reduction of debtfrom a 140 percent decrease in Mozambique to a 17 percent increase in the Democratic Republic of Congo. One of the main reason for this difference in performance is the quality

41 This is not to say that there were no reforms concerning the budgetary framework. But the complete re-structuring of fiscal policies took mostly place in the 1990s. 
of BI. Between the late 1990's and the early 2000's several of the countries included in the sample introduced major structural reforms in PFM which in turn affected fiscal performance. To illustrate this point, I regress the difference between the debt to GDP ratio in 1990 and the debt to GDP ratio in 2007 on the same control variables as depicted in Table 9. The results are depicted below in Table 11. The coefficient of the BI index is very large and highly significant. Apart from centralization which has a small and highly insignificant coefficient, all the other categories have positive and large coefficients. 
Table 11: Difference in Public External Debt between 1990 and 2000 with Equal Weights Index

\begin{tabular}{|c|c|c|c|c|c|c|c|}
\hline & $\begin{array}{c}\text { WITHOUT } \\
\text { BI }\end{array}$ & $\begin{array}{c}\text { WITH } \\
\text { BI }\end{array}$ & CENTRALIZATION & P RULES & "SUSTAINAB'Y & COMPREHENSIV'S & TRANSPARENCY \\
\hline VARIABLES & ped_diff & ped_diff & ped_diff & ped_diff & ped_diff & ped_diff & ped_diff \\
\hline \multirow[t]{2}{*}{ Growth } & 3.081 & 1.768 & 3.159 & 2.378 & 2.717 & 2.495 & 1.382 \\
\hline & $(2.281)$ & $(2.295)$ & $(2.356)$ & $(2.061)$ & $(1.940)$ & $(2.329)$ & $(2.280)$ \\
\hline \multirow[t]{2}{*}{ gdppc_2002 } & -0.0211 & -0.0713 & -0.0170 & -0.0868 & -0.0411 & -0.0248 & -0.0754 \\
\hline & $(0.108)$ & $(0.101)$ & $(0.117)$ & $(0.110)$ & $(0.0972)$ & $(0.106)$ & $(0.102)$ \\
\hline \multirow[t]{2}{*}{ Trade } & 0.334 & 0.487 & 0.383 & 0.832 & 1.230 & 0.223 & 0.349 \\
\hline & $(1.466)$ & $(1.277)$ & $(1.541)$ & $(1.415)$ & $(1.383)$ & $(1.363)$ & $(1.323)$ \\
\hline \multirow[t]{2}{*}{ Resources } & 0.165 & 0.228 & 0.156 & 0.186 & 0.189 & 0.203 & 0.185 \\
\hline & $(0.194)$ & $(0.180)$ & $(0.223)$ & $(0.181)$ & $(0.180)$ & $(0.187)$ & $(0.173)$ \\
\hline \multirow[t]{2}{*}{ Hipcc } & $0.303^{*}$ & 0.220 & 0.311 & 0.112 & $0.332 *$ & 0.272 & $0.277^{*}$ \\
\hline & $(0.175)$ & $(0.166)$ & $(0.197)$ & $(0.177)$ & $(0.164)$ & $(0.164)$ & $(0.158)$ \\
\hline \multirow[t]{2}{*}{ Fractionalization } & 0.251 & 0.166 & 0.241 & 0.265 & 0.141 & 0.149 & 0.151 \\
\hline & $(0.331)$ & $(0.351)$ & $(0.342)$ & $(0.360)$ & $(0.357)$ & $(0.346)$ & $(0.345)$ \\
\hline \multirow[t]{2}{*}{ Index } & & $0.951 *$ & & & & & \\
\hline & & $(0.479)$ & & & & & \\
\hline \multirow[t]{2}{*}{ Centralization } & & & -0.0648 & & & & \\
\hline & & & $(0.426)$ & & & & \\
\hline \multirow[t]{2}{*}{ Rules } & & & & $0.892 * *$ & & & \\
\hline & & & & $(0.392)$ & & & \\
\hline \multirow[t]{2}{*}{ Sustainability } & & & & & $0.688^{*}$ & & \\
\hline & & & & & $(0.368)$ & & \\
\hline \multirow[t]{2}{*}{ Comprehensiveness } & & & & & & 0.343 & \\
\hline & & & & & & $(0.297)$ & \\
\hline \multirow[t]{2}{*}{ Transparency } & & & & & & & $0.630 * *$ \\
\hline & & & & & & & $(0.300)$ \\
\hline \multirow[t]{2}{*}{ Constant } & 0.0635 & 0.0805 & 0.0702 & 0.170 & -0.0937 & 0.0171 & 0.338 \\
\hline & $(0.994)$ & $(0.933)$ & $(1.013)$ & $(0.972)$ & $(0.945)$ & $(0.977)$ & $(0.946)$ \\
\hline Observations & 39 & 39 & 39 & 39 & 39 & 39 & 39 \\
\hline R-squared & 0.264 & 0.344 & 0.265 & 0.345 & 0.334 & 0.292 & 0.363 \\
\hline
\end{tabular}

Robust standard errors in parentheses; $* * * p<0.01, * * p<0.05, * p<0.1$

(Namibia missing, because no observation was available for 1990) 
Another potential problem may be caused by missing variables: if I have omitted important institutional variables that drive fiscal outcomes, the effect of BI may be overstated. To control for the broader institutional framework, I added the variables political stability (stability), xconst (constraints on the executive) and control of corruption (control) to the regressions depicted in Table 9 and 10. This did not affect the general results. The coefficient associated with control of corruption was highly insignificant and positive in the regression for debt and negative and insignificant in the regression for the primary balance as depicted in Tables A-V 4 and A-V 5 in the appendix. ${ }^{42}$ The coefficient associated with political stability was insignificant and negative in both regressions. ${ }^{43}$ Furthermore, to control for the effect of IMF programs on fiscal discipline, I added a dummy variable for the presence of a poverty reduction strategy program (prgf) in the country. The coefficient associated with this dummy variable was highly insignificant and positive for the debt regression and positive and insignificant for the primary budget balance regression as depicted in Tables A-V 6 and A-V 7 in the appendix. Again, the overall findings were not affected. To ensure that the regressions described in this paragraph do not suffer from high levels of multicollinearity, which could arise if the broader institutional variables are highly correlated with the BI index, I examine the Spearman rank correlations between my index and the four additional control variables. Only the correlation with constraints on the executive is statistically significant at the ten percent level. The correlation is also strongest with constraints on the executive and corruption (with $\rho$ equal to 0.312 and 0.238 respectively) and considerably weaker for political stability and $\operatorname{prgf}$ (with $\rho$ equal to 0.117 and 0.0285 respectively). This suggests that there might indeed be a slight multicollinearity problem for the regressions including constraints on the executive and corruption. The results should therefore be interpreted with this caveat in mind.

\footnotetext{
42 Note that the latter result may be explained by the findings by Thornton (2008) which suggest that more corrupt governments are more likely to conduct countercyclical fiscal policies.

43 Note that the variables political stability and constraints on the executive were only available for a smaller sample of countries. These results are available upon request.
} 
Moreover, if my index serves only as indicator of the actual, unobservable institutional quality, the problem of measurement errors may lead to biased and inconsistent results. A possible solution is offered by Dagenais and Dagenais (1997) and Arcand and Dagenais (2005) who show that a nonlinear transformation of a variable can serve as an instrument for the original indicator. ${ }^{44}$ I therefore try running a two-stage regression with the geometrically aggregated index as instrumental variable for the equal weights index. The subsequent Hausman test fails to reject exogeneity thus indicating that this particular IV strategy does not represent a superior estimation method. An alternative solution would be to follow the multiple indicator solution proposed by Wooldridge (2002). Yet, as this paper contains the first dataset on African budget institutions comprising almost all AU members states, a second indicator is simply not available. The problem of measurement errors therefore remains largely unsolved.

Finally, the regressions presented above may suffer from endogeneity. It is possible that better fiscal outcomes may lead to better budget institutions. This would, for example, be the case if budgetary reforms were tightly linked to IMF programs which are introduced in response to fiscal performance. In that case the quality of budget institutions could be expected to be endogenous to prior fiscal performance. I tested this possibility by considering the Spearman rank correlations between prgf and BI which, as stated above is very small and insignificant thus suggesting that this correlation may not be strong enough to cause endogeneity. To test if other forms of official development aid could be the cause for improvements in budgetary institutions, I tested the Spearman rank correlation between the net official development assistance and development aid received (aid) and budget

$44 \quad$ Two assumptions have to hold for this: first, the measurement errors of the variable which is to be instrumented by its own nonlinear transformation are normally distributed. Second, it has to be assumed that "(i) the errors in the variables are independent between observations, but (ii) not between variables" (Arcand and Dagenais, 2005). The second assumption is reasonable, in the context of my index. There is no reason why the measurement errors should be correlated across countries, while it is quite likely that within the same country there is a similar measurement error across different index components. Normality of the measurement errors, however, is a strong assumption. Yet, if it is reasonable to assume that measurement errors are related to the general quality of available data in the country, then the distribution of the transparency score of the index might reflect the distribution of the measurement errors. As the transparency scores seem to be distributed normally I can use a nonlinear transformation of my index as an instrumental variable. 
institutions. The correlation is relatively weak $(\rho=0.115)$ and insignificant $(p=0.481)$ thereby further attenuating the suspicion of endogeneity. ${ }^{45}$ Furthermore, budget institutions are costly to change and should therefore be more stable than fiscal outcomes-at least in the short- to medium-run. Nevertheless, the results presented in this paper clearly can only be considered as preliminary, since there are a number of econometric problems that could not be solved in the above framework.

\section{CONCLUDING REMARKS}

This paper has constructed a new and Africa-specific composite indicator for the quality of budgetary institutions. Unlike earlier studies, the analysis includes almost all AU member states. The resulting index scores demonstrate the large differences in institutional quality across the continent, thereby highlighting the importance and potential of initiatives like CABRI which might enable countries with weak institutions to benefit from the experience of the top performers in institutional quality, such as Namibia. It has been shown that good budgetary institutions are associated with lower levels of external government debt and-less significantly - a higher primary balance. The quality of budget institutions, as measured in this paper, represents an indicator of inter-temporal fiscal discipline and might therefore serve external donors as a criterion for decisions on direct budget support. Moreover, the significant correlation of the centralization sub-index with external debt and of the transparency sub-index with the budget balance highlight the importance of top-down procedural rules and of the central budget authority's communication with and accountability to the public throughout the entire budget process.

Yet, good institutions are only "the rules of the game", as North (1990) puts it. Their effect on actual outcomes depends greatly on the government's willingness to obey these rules. Institutions can only have an impact if they are adhered to by the main players. It is with this caveat that all de iure measures of institutional quality-including the one constructed in this paper-have to be interpreted.

45 This also suggests that better BI do not only improve fiscal performance through attracting more aid. 


\section{ACKNOWLEDGEMENTS}

I would like to thank Charles Wyplosz, Ugo Panizza, Jean-Louis Arcand, Marc Quintyn, Lucie Gadenne, and Benedikt Franke for their helpful comments on earlier versions of this paper. I am also endebted to Era Dabla-Norris, Louis-Felipe Zanna, Eteri Kvintradze, Richard Allen, Tej Prakash, Irene Yackovlev and Victor Lledo from whose suggestions I greatly benefited while working on our co-authored IMF Working Paper on budget institutions and fiscal performance in low-income countries. Naturally, I am solely responsible for any remaining mistakes and shortcomings. 


\section{REFERENCES}

Alesina, A. and R. Perotti (1994) "The Political Economy of Budget Deficits." NBER Working Paper No. 4637. National Bureau of Economic Research: Cambridge, MA.

Alesina, A. and R. Perotti (1996) "Budget Deficits and Budget Institutions." NBER Working Paper 5556. National Bureau of Economic Research: Cambridge, MA.

Alesina, A. and G. Tabellini (1990) "A Positive Theory of Fiscal Deficits and Government Debts." The Review of Economic Studies, 57:3, pp. 403-14.

Alesina, A, R. Hausmann, R. Hommes, and E. H. Stein. (1999) "Budget Institutions and Fiscal Performance in Latin America." Journal of Development Economics, 59, pp. 253-73.

Alt, J. E. and D. Dreyer Lassen (2003) "Fiscal Transparency and Fiscal Outcomes in OECD Countries." Economic Policy Research Unit, University of Copenhagen: Copenhagen.

Arcand, J. and M. Dagenais (2005) "Errors in Variables and the Empirics of Economic Growth."

CABRI/ AfDB (2008) "Report on Budget Practices and Procedures". Collaborative African Budget Reform Initiative and African Development Bank: Preotoria and Tunis.

Dabla-Norris, E., R. Allen, F. Zanna, T. Prakash, E. Kvitradze, V. Lledo, I. Yackovlev, and S. Gollwitzer (2010) "Budget Institutions and Fiscal Performance in Low- Income Countries." IMF WP/10/80. International Monetary Fund: Washington, D.C..

Dagenais, M. and D. L. Dagenais (1997) "Higher Moment Estimators for Linear Regression Models with Errors in the Variables." Journal of Econometrics, 76:1-2, pp. 193-221.

De Crombrugghe, Denis, Kristine Farla, Nicolas Meisel, Chris de Neubourg, Jacques Ould Aoudia, andAdam Szirma. 2006. "Institutional Profiles Database." CEPII.

Economist Intelligence Unit (2008) "The Economist Intelligence Unit's Index of Democracy 2008". www.eiu.com.

Fabrizio, S. and A. Mody (2006) "Can Budget Institutions Counteract Political Indiscipline?" IMF WP/06/123. International Monetary Fund: Washington, D.C.

Hallerberg, M., R. Strauch, and J. Von Hagen (2004) "The Design of Fiscal Rules and Forms of Governance in European Union Countries." ECB Working Paper No. 419 European Central Bank: Frankfurt.

Hallerberg, M. and J. Von Hagen. (1999) "Electoral Institutions, Cabinet Negotiations, and Budget Deficits within the European Union," in Fiscal Institutions and Fiscal Performance. James Poterba and Jürgen von Hagen eds. Chicago: University of Chicago Press, pp. 209-32.

Hameed, F. (2005) "Fiscal Transparency and Economic Outcomes." IMF Working Paper No.05/225. International Monetary Fund: Washington, D.C. 
Harden, I. and J. Von Hagen (1994) "National Budget Processes and Fiscal Performance." European Economy Reports and Studies, 3, pp. 311-418.

Harden, I. and J. Von Hagen (1995) "Budget Processes and Commitment to Fiscal Discipline." European Economic Review, 39:3-4, pp. 771-79.

International Budget Partnership (2008) "Open Budget Index." Center on Budget and Policy Priorities: Washington, D.C.

IMF (forthcoming) "Fiscal Consolidation in G-20 Countries: The Role of Budget Institutions." International Monetary Fund: Washington, D.C.

Le Houerou, P. and R. Taliercio (2002) "Medium Term Expenditure Frameworks: From Concept to Practice. Preliminary Lessons from Africa." Africa Region Working Paper Series No. 28. World Bank: Washington, DC.

Ljungman, G. (2009) "Top-Down Budgeting - An Instrument to Strengthen Budget Management." IMF Working Paper WP/09/243. International Monetary Fund: Washington, DC.

Marshall, Monty G. and Keith Jaggers. 2008. "Polity IV Project: Political Regime Characteristics and Transitions, 1800-2008." Center for Systemic Peace.

Mehran, H., P. Hayward, G. Iden, T. Lybek, S. Swaray, P. Ugolini, and J. Briffaut (1998). "Financial Sector Development in Sub-Saharan African Countries." IMF Occasional Paper No.169. International Monetary Fund.

Mulas-Granados, C., J. Onrubia, and J. Salinas-Jeménez (2009) "Do Budget Institutions Matter? Fiscal Consolidation in the New EU Member States." Eastern European Economics, 47:1, pp. 60-91.

North, D. (1990) Institutions, Institutional Change and Economic Performance. Cambridge: Cambridge University Press.

O'Connell, S. (1988) "Fiscal Policy in Low-Income Africa". WPS 39. The World Bank: Washington, DC.

ODI. (2005) "Linking Policies and Budgets: Implementing Medium Term Expenditure Frameworks in a PRSP Context." Briefing Paper. Overseas Development Institute: London.

OECD (2006) "Collaborative African Budget Initiative." OECD Journal on Budgeting, Vol. 6,2. Organization for Economic Cooperation and Development. OECD: Paris.

OECD (2008 a) "Handbook on Constructing Composite Indicators: Methodology and User Guide." OECD: Paris.

OECD (2008 b) "International Budget Practices and Procedures Database." OECD: Paris.

PEFA (2007) "Public Expenditutre and Financial Accountability Reports." The World Bank: Washington, D.C. 
Persson, T. and G. Tabellini (2000) Political Economics, Explaining Economic Policy. Cambridge, MA: MIT Press.

Poterba, J. (1996) "Budget Institutions and Fiscal Policy in the U.S. States." NBER Working Paper 5449. National Bureau of Economic Research: Cambridge, MA.

Potter, B. and J. Diamond (1999) "Guidelines for Public Expenditure Management." IMF WP/99/. International Monetary Fund: Washington, D.C.

Prakash, T. and C. Ezequiel (2008) "Public Financial Management and Fiscal Outcomes in SubSaharan African Heavily-Indebted Poor Countries." IMF WP/08/217. International Monetary Fund: Washington, D.C.

Pritchett, L. (1996) "Where Has All the Education Gone?" Policy Research Working Paper 1581. The World Bank: Washington, DC.

Saitoti, G. (2002) The challenges of economic and institutional reforms in Africa. Aldershot; Burlington, VT: Ashgate.

Schick, A. (1998) A Contemporary Approach to Public Expenditure Management: World Bank Institute.

Shah, A. (2005) "Fiscal Management." Public Sector Governance and Accountability Series. The World Bank: Washington, DC.

Shah, A. (2007) Budgeting and Budgetary Institutions. Washington, DC: The World Bank.

Siebritz, K- and E. Calitz (2006). "The legacy and challenge of fiscal policy in sub-Saharan Africa". Paper presented at the XIVth International Economic History Conference.

Stevens, M. (2004) "Institutional and Incentive Issues in Public Financial Management Reform in Poor Countries." World Bank: Washington, D.C.

Thornton J (2008). "Explaining Procyclical Fiscal Policy in African Countries". Journal of African Economies, 17 (3), pp. 451-464.

Von Hagen, J. (1992) "Budgeting Procedures and Fiscal Performance in the European Communities " European Economy - Economic Papers, Vol. 96. Commission of the EC, Directorate-General for Economic and Financial Affairs (DG ECFIN)

Wooldridge, J. (2002) Econometric Analysis of Cross Section and Panel Data. Cambridge, MA: MIT Press.

The World Bank Group (2009) "Reports on the Observance of Standards and Codes." World Bank: Washington, D.C.

Wyplosz, C. and S. Krogstrup (2006) "A Common Pool Theory of Deficit Bias Correction." Discussion Paper No. 5866. Centre for Economic Policy Research: Geneva. 


\section{APPENDIX I: INDEX COMPONENTS AND SCORING SCHEME}

Table A-I 1: Budget Institutions Index

\begin{tabular}{|c|c|c|c|c|c|}
\hline & $\overline{\mathbf{0}}$ & 0.25 & 0.5 & $\overline{0.75}$ & 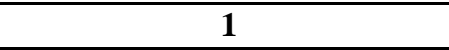 \\
\hline \multicolumn{6}{|c|}{ Phase 1: Budget Planning and Negotiation } \\
\hline \multicolumn{6}{|l|}{ Centralization } \\
\hline $\begin{array}{l}\text { Legal Vesting of } \\
\text { Power }\end{array}$ & $\begin{array}{l}\text { Several ministries or } \\
\text { governmental bodies. }\end{array}$ & & & & $\begin{array}{l}\text { MoF/CBA clearly identified as } \\
\text { primary general budget officer. }\end{array}$ \\
\hline Agenda Setting & $\begin{array}{l}\text { MoF/CBA or } \\
\text { cabinet directly } \\
\text { collects } \\
\text { bids from } \\
\text { spending ministers. }\end{array}$ & $\begin{array}{l}\text { MoF/CBA sends out } \\
\text { some guidelines to } \\
\text { line ministries, no } \\
\text { ceilings or } \\
\text { macroeconomic } \\
\text { guidelines. } \\
\text { Alternatively, targets } \\
\text { are included but } \\
\text { cabinet first has to } \\
\text { vote on them. }\end{array}$ & $\begin{array}{l}\text { MoF/CBA sends } \\
\text { out some } \\
\text { guidelines to line } \\
\text { ministries with } \\
\text { macroeconomic } \\
\text { guidelines but no } \\
\text { spending ceilings } \\
\text { or targets. }\end{array}$ & $\begin{array}{l}\text { MoF/CBA sends out } \\
\text { some guidelines to } \\
\text { line ministries with } \\
\text { macroeconomic } \\
\text { guidelines and } \\
\text { spending ceilings or } \\
\text { targets. Conflicts are } \\
\text { resolved by cabinet } \\
\text { or other executive } \\
\text { body. }\end{array}$ & $\begin{array}{l}\text { MoF/CBA sends out some } \\
\text { guidelines to line ministries } \\
\text { with macroeconomic guidelines } \\
\text { and spending ceilings or } \\
\text { targets. In case of conflict } \\
\text { MoF/CBA has the last word. }\end{array}$ \\
\hline \multicolumn{6}{|l|}{ Rules and Controls } \\
\hline Fiscal Rules & None & Expenditure rules. & $\begin{array}{l}\text { Expenditure and } \\
\text { Revenue rule. }\end{array}$ & Budget balance rule. & $\begin{array}{l}\text { Debt rule (and possibly other } \\
\text { rules). }\end{array}$ \\
\hline Sector Budget Ceilings & None & Only indicative. & $\begin{array}{l}\text { Yes for some } \\
\text { sectors. }\end{array}$ & $\begin{array}{l}\text { For all types on a } \\
\text { chapter level. }\end{array}$ & For all types on a line-level. \\
\hline \multicolumn{6}{|l|}{ Sustainability and Credibility } \\
\hline $\begin{array}{l}\text { Multiannual } \\
\text { expenditure plans }\end{array}$ & No. & $\begin{array}{l}\text { At least three year } \\
\text { expenditure plans at } \\
\text { the aggregate level. }\end{array}$ & $\begin{array}{l}\text { At least three year } \\
\text { expenditure plans } \\
\text { at the aggregate } \\
\text { level and for some } \\
\text { key ministries. }\end{array}$ & $\begin{array}{l}\text { At least three year } \\
\text { expenditure plans at } \\
\text { the ministry or line } \\
\text { level. }\end{array}$ & $\begin{array}{l}\text { More than three year } \\
\text { expenditure plans at the } \\
\text { ministry or line level. }\end{array}$ \\
\hline $\begin{array}{l}\text { Macro-/ Fiscal } \\
\text { Framework }\end{array}$ & None & $\begin{array}{l}\text { There exist key } \\
\text { variables or } \\
\text { assumptions on } \\
\text { which fiscal planning }\end{array}$ & $\begin{array}{l}\text { There is a } \\
\text { methodology or } \\
\text { model which is } \\
\text { based on certain }\end{array}$ & $\begin{array}{l}\text { There is a } \\
\text { methodology or } \\
\text { model which is } \\
\text { based on certain }\end{array}$ & $\begin{array}{l}\text { There is a macroeconomic } \\
\text { model which is based on clear } \\
\text { assumptions and produces } \\
\text { detailed projections. }\end{array}$ \\
\hline
\end{tabular}




\begin{tabular}{|c|c|c|c|c|c|}
\hline & & is always based. & $\begin{array}{l}\text { assumptions and } \\
\text { produces some } \\
\text { projections. } \\
\end{array}$ & $\begin{array}{l}\text { assumptions and } \\
\text { produces detailed } \\
\text { projections. } \\
\end{array}$ & \\
\hline Sectoral Framework & None & $\begin{array}{l}\text { Some discussion of } \\
\text { objectives and } \\
\text { strategy for a few } \\
\text { sectors. }\end{array}$ & $\begin{array}{l}\text { Strategic plan, } \\
\text { objectives and } \\
\text { expected output for } \\
\text { priority sectors. }\end{array}$ & $\begin{array}{l}\text { Sectoral objectives } \\
\text { and strategic } \\
\text { planning, objectives } \\
\text { and expected output } \\
\text { for priority sectors. }\end{array}$ & $\begin{array}{l}\text { Strategic plan, objectives, and } \\
\text { expected output per sector and } \\
\text { activity. }\end{array}$ \\
\hline \multicolumn{6}{|l|}{ Comprehensiveness } \\
\hline Dual Budgeting & $\begin{array}{l}\text { Dual budgeting: } \\
\text { separate budgets for } \\
\text { recurrent costs and } \\
\text { for investment. }\end{array}$ & & $\begin{array}{l}\text { Only formally } \\
\text { integrated. } \\
\text { Preparation and } \\
\text { structure separate. }\end{array}$ & & $\begin{array}{l}\text { Integrated budget including } \\
\text { both recurrent costs and } \\
\text { investment spending. }\end{array}$ \\
\hline $\begin{array}{l}\text { Size of Off-Budget } \\
\text { Items }\end{array}$ & $\begin{array}{l}\text { Greater or equal to } \\
10 \text { percent of total } \\
\text { expenditure in } \\
\text { central government } \\
\text { budget or not } \\
\text { available. }\end{array}$ & $\begin{array}{l}\text { Greater or equal to } 8 \\
\text { percent of total } \\
\text { expenditure in } \\
\text { central government } \\
\text { budget. }\end{array}$ & $\begin{array}{l}\text { Greater or equal to } \\
6 \text { percent of total } \\
\text { expenditure in } \\
\text { central government } \\
\text { budget. }\end{array}$ & $\begin{array}{l}\text { Greater or equal to } 4 \\
\text { percent of total } \\
\text { expenditure in } \\
\text { central government } \\
\text { budget. }\end{array}$ & $\begin{array}{l}\text { Under } 4 \text { percent of total } \\
\text { expenditure in central } \\
\text { government budget. }\end{array}$ \\
\hline Inclusion of Aid & $\begin{array}{l}\text { Projects funded with } \\
\text { aid not included in } \\
\text { budget }\end{array}$ & $\begin{array}{l}\text { Only some aid flows } \\
\text { included. }\end{array}$ & $\begin{array}{l}\text { Majority of aid } \\
\text { flows but less than } \\
2 / 3 \text { are included. }\end{array}$ & $\begin{array}{l}\text { At least } 2 / 3 \text { but not } \\
\text { all of aid flows are } \\
\text { included in budget } \\
\text { documents. }\end{array}$ & $\begin{array}{l}\text { All and entire projects funded } \\
\text { by aid are included. }\end{array}$ \\
\hline Inclusion of Debt & $\begin{array}{l}\text { No information on } \\
\text { outstanding debt } \\
\text { included. }\end{array}$ & $\begin{array}{l}\text { Some information on } \\
\text { outstanding debt } \\
\text { included. }\end{array}$ & $\begin{array}{l}\text { Yes, information } \\
\text { on outstanding } \\
\text { debt is included. }\end{array}$ & $\begin{array}{l}\text { Yes, some } \\
\text { information on debt } \\
\text { and interest } \\
\text { payments included. } \\
\text { But lacks important } \\
\text { details. }\end{array}$ & $\begin{array}{l}\text { Yes, detailed information on } \\
\text { outstanding debt and interest } \\
\text { payments on outstanding debt } \\
\text { included. }\end{array}$ \\
\hline \multicolumn{6}{|l|}{ Transparency } \\
\hline $\begin{array}{l}\text { Clarity of Roles and } \\
\text { Responsibilities }\end{array}$ & $\begin{array}{l}\text { The roles and } \\
\text { responsibilities are } \\
\text { not clearly defined } \\
\text { and might even }\end{array}$ & & $\begin{array}{l}\text { The role of the } \\
\text { CBA and of a few } \\
\text { key roles is } \\
\text { defined but the }\end{array}$ & & $\begin{array}{l}\text { The legal framework codifies } \\
\text { all key aspects of financial } \\
\text { management at the central, } \\
\text { sectoral and regional level. }\end{array}$ \\
\hline
\end{tabular}




\begin{tabular}{|c|c|c|c|c|c|}
\hline & $\begin{array}{l}\text { change from year to } \\
\text { year. }\end{array}$ & & $\begin{array}{l}\text { detailed } \\
\text { responsibilities are } \\
\text { not defined. No } \\
\text { mentioning in } \\
\text { constitution. }\end{array}$ & & $\begin{array}{l}\text { Enshrined in constitution. Or } \\
\text { other relevant legal text. }\end{array}$ \\
\hline $\begin{array}{l}\text { Publication of Draft } \\
\text { Budget }\end{array}$ & No & & $\begin{array}{l}\text { Only a few key } \\
\text { parts of draft } \\
\text { budget are } \\
\text { published. }\end{array}$ & & $\begin{array}{l}\text { Draft budget published entirely } \\
\text { or in great parts. }\end{array}$ \\
\hline $\begin{array}{l}\text { Publication of } \\
\text { Macroeconomic } \\
\text { Forecasts and } \\
\text { Assumptions }\end{array}$ & No & $\begin{array}{l}\text { There is some } \\
\text { discussion of the } \\
\text { macroeconomic } \\
\text { forecast but the } \\
\text { assumptions are not } \\
\text { discussed. }\end{array}$ & $\begin{array}{l}\text { There is some } \\
\text { discussion of the } \\
\text { macroeconomic } \\
\text { forecast and the } \\
\text { key assumptions } \\
\text { but important } \\
\text { details are missing. }\end{array}$ & $\begin{array}{l}\text { Yes, the } \\
\text { macroeconomic } \\
\text { forecast is discussed } \\
\text { and most of the key } \\
\text { assumptions are } \\
\text { stated explicitly, but } \\
\text { some details are } \\
\text { excluded. }\end{array}$ & $\begin{array}{l}\text { Yes, an extensive discussion of } \\
\text { the macroeconomic forecast is } \\
\text { presented, and key assumptions } \\
\text { (such as inflation, real GDP } \\
\text { growth, unemployment rate, } \\
\text { and interest rates) are stated } \\
\text { explicitly. }\end{array}$ \\
\hline $\begin{array}{l}\text { Information on } \\
\text { Macroeconomic Risks }\end{array}$ & No. & & $\begin{array}{l}\text { On an ad-hoc basis } \\
\text { or only for selected } \\
\text { variables. }\end{array}$ & & Yes. \\
\hline \multicolumn{6}{|l|}{ Phase 2: Budget Approval } \\
\hline \multicolumn{6}{|l|}{ Centralization } \\
\hline $\begin{array}{l}\text { Amendments by } \\
\text { Legislature }\end{array}$ & $\begin{array}{l}\text { Unlimited or not at } \\
\text { all allowed to amend. }\end{array}$ & $\begin{array}{l}\text { Within certain loose } \\
\text { limits, legislature can } \\
\text { change expenditure, } \\
\text { strategies and } \\
\text { priorities. }\end{array}$ & $\begin{array}{l}\text { Legislature may } \\
\text { adjust spending } \\
\text { upward and } \\
\text { downward within } \\
\text { clearly defined } \\
\text { limits. }\end{array}$ & $\begin{array}{l}\text { Amendments cannot } \\
\text { increase overall } \\
\text { expenditure. } \\
\text { Increase in spending } \\
\text { on one item has to } \\
\text { be matched by } \\
\text { decrease on another. }\end{array}$ & $\begin{array}{l}\text { Legislature cannot increase or } \\
\text { create new expenditure. It can } \\
\text { only decrease expenditure. }\end{array}$ \\
\hline Executive Veto & $\begin{array}{l}\text { No or not legally } \\
\text { regulated and not } \\
\text { limited. }\end{array}$ & & & & $\begin{array}{l}\text { Yes and legally regulated and } \\
\text { limited. }\end{array}$ \\
\hline \multicolumn{6}{|l|}{ Rules and Controls } \\
\hline Time Limit & Inflexible time limit & No time limit. & Budget has to be & Budget has to be & Budget has to be approved \\
\hline
\end{tabular}




\begin{tabular}{|c|c|c|c|c|c|}
\hline & $\begin{array}{l}\text { equal to or shorter } \\
\text { than one month or } \\
\text { Parliament does not } \\
\text { receive budget before } \\
\text { start of fiscal year. }\end{array}$ & & $\begin{array}{l}\text { approved before } \\
\text { start of the fiscal } \\
\text { year. }\end{array}$ & $\begin{array}{l}\text { approved before } \\
\text { start of the fiscal } \\
\text { year and within } \\
\text { reasonable fixed } \\
\text { time limits. }\end{array}$ & within two to three months. \\
\hline $\begin{array}{l}\text { Procedure in Case of } \\
\text { Failed Approval }\end{array}$ & $\begin{array}{l}\text { The Executive's } \\
\text { budget proposal } \\
\text { takes effect. }\end{array}$ & $\begin{array}{l}\text { The Executive's } \\
\text { budget proposal } \\
\text { takes effect on an } \\
\text { interim basis, i.e. for } \\
\text { a limited period. }\end{array}$ & $\begin{array}{l}\text { Last year's budget } \\
\text { takes effect on an } \\
\text { interim basis, i.e. } \\
\text { for a limited } \\
\text { period. }\end{array}$ & $\begin{array}{l}\text { Other interim } \\
\text { measures are voted } \\
\text { on by Legislature. }\end{array}$ & $\begin{array}{l}\text { Expenditure without legislative } \\
\text { approval is not allowed. }\end{array}$ \\
\hline \multicolumn{6}{|l|}{ Sustainability and Credibility } \\
\hline Scope of Approval & $\begin{array}{l}\text { Legislature approves } \\
\text { only current budget. }\end{array}$ & & $\begin{array}{l}\text { There is no formal } \\
\text { debate on overall } \\
\text { budget policy but } \\
\text { some form of } \\
\text { discussion in } \\
\text { committee } \\
\text { sessions. }\end{array}$ & & $\begin{array}{l}\text { Legislature debates overall } \\
\text { budget policy prior to or after } \\
\text { introduction of Executive's } \\
\text { budget proposal. }\end{array}$ \\
\hline Capacity & $\begin{array}{l}\text { No special } \\
\text { arrangements. }\end{array}$ & $\begin{array}{l}\text { No experts but } \\
\text { random training } \\
\text { offered to } \\
\text { committees. }\end{array}$ & $\begin{array}{l}\text { Formation of } \\
\text { working groups } \\
\text { according to } \\
\text { experience without } \\
\text { special training. }\end{array}$ & $\begin{array}{l}\text { Formation of } \\
\text { working groups } \\
\text { according to } \\
\text { expertise and some } \\
\text { training offered. }\end{array}$ & $\begin{array}{l}\text { Establishment of research } \\
\text { bureaus or units consisting of } \\
\text { trained experts. }\end{array}$ \\
\hline \multicolumn{6}{|l|}{ Comprehensiveness } \\
\hline Voting sequence & Other. & & & & $\begin{array}{l}\text { Legislature first votes on entire } \\
\text { budget then on individual } \\
\text { spending items. }\end{array}$ \\
\hline $\begin{array}{l}\text { Hearings/Votes on } \\
\text { Individual Budgets }\end{array}$ & None. & $\begin{array}{l}\text { A limited number of } \\
\text { hearings for } \\
\text { clarification. But } \\
\text { legislative does not } \\
\text { vote on individual } \\
\text { budgets. }\end{array}$ & $\begin{array}{l}\text { A limited number } \\
\text { of hearings are } \\
\text { held in which } \\
\text { testimony from the } \\
\text { executive branch is } \\
\text { heard and } \\
\text { legislative votes on }\end{array}$ & $\begin{array}{l}\text { Hearings are held, } \\
\text { covering key } \\
\text { administrative units, } \\
\text { in which testimony } \\
\text { from the executive } \\
\text { branch is heard and } \\
\text { legislative votes on }\end{array}$ & $\begin{array}{l}\text { Extensive hearings are held on } \\
\text { the budgets of administrative } \\
\text { units in which testimony from } \\
\text { the executive branch is heard. } \\
\text { Legislature votes on all } \\
\text { individual unit budgets. }\end{array}$ \\
\hline
\end{tabular}




\begin{tabular}{|c|c|c|c|c|c|}
\hline & & & $\begin{array}{l}\text { some key } \\
\text { allocations. }\end{array}$ & $\begin{array}{l}\text { all individual unit } \\
\text { budgets. }\end{array}$ & \\
\hline \multicolumn{6}{|l|}{ Transparency } \\
\hline $\begin{array}{l}\text { Public Hearings on } \\
\text { Overall Budget Policy. }\end{array}$ & No. & $\begin{array}{l}\text { No, but short press } \\
\text { statements. }\end{array}$ & $\begin{array}{l}\text { No, but summary } \\
\text { published. }\end{array}$ & $\begin{array}{l}\text { No, but detailed } \\
\text { report published or } \\
\text { life broadcast. }\end{array}$ & Yes. \\
\hline $\begin{array}{l}\text { Public Hearings on } \\
\text { Individual Budgets }\end{array}$ & No. & $\begin{array}{l}\text { No, but short press } \\
\text { statements. }\end{array}$ & $\begin{array}{l}\text { No, but summary } \\
\text { published. }\end{array}$ & $\begin{array}{l}\text { No, but detailed } \\
\text { report published or } \\
\text { life broadcast. }\end{array}$ & Yes. \\
\hline \multicolumn{6}{|l|}{ Phase 3: Budget Implementation } \\
\hline \multicolumn{6}{|l|}{ Centralization } \\
\hline $\begin{array}{l}\text { Disbursement } \\
\text { Specification }\end{array}$ & $\begin{array}{l}\text { Yes, each } \\
\text { agency/executive } \\
\text { organisation receives } \\
\text { a lump sum } \\
\text { appropriation } \\
\text { covering both } \\
\text { operating and capital } \\
\text { expenditures, without } \\
\text { sub-limits or } \\
\text { guidelines. }\end{array}$ & $\begin{array}{l}\text { Yes, each } \\
\text { agency/executive } \\
\text { organisation receives } \\
\text { a lump sum } \\
\text { appropriation } \\
\text { covering both } \\
\text { operating and capital } \\
\text { expenditures, with a } \\
\text { sub-limit on wages } \\
\text { or certain guidelines. }\end{array}$ & \begin{tabular}{|l|} 
Yes, each \\
agency/executive \\
organisation \\
receives a lump \\
sum appropriation \\
for operating \\
expenditures only, \\
without sub-limits
\end{tabular} & \begin{tabular}{|l} 
Yes, each \\
agency/executive \\
organisation \\
receives a lump sum \\
appropriation for \\
operating \\
expenditures only, \\
with a sub-limit on \\
wages or strict \\
guidelines. \\
\end{tabular} & $\begin{array}{l}\text { No, each agency/executive } \\
\text { organisation receives an } \\
\text { appropriation that specifies } \\
\text { expenditures below the agency } \\
\text { level. }\end{array}$ \\
\hline \multicolumn{6}{|l|}{ Rules and Controls } \\
\hline Audit body & $\begin{array}{l}\text { No external audit } \\
\text { body. }\end{array}$ & $\begin{array}{l}\text { External audit body } \\
\text { but not fully } \\
\text { independent. }\end{array}$ & \begin{tabular}{|l|} 
External and \\
legally \\
independent audit \\
body. Does not \\
publish reports.
\end{tabular} & $\begin{array}{l}\text { External and legally } \\
\text { independent audit } \\
\text { body. Publishes } \\
\text { reports but does not } \\
\text { suggest } \\
\text { punishments. } \\
\end{array}$ & $\begin{array}{l}\text { External and legally } \\
\text { independent audit. Publishes } \\
\text { reports and can suggest } \\
\text { punishments. }\end{array}$ \\
\hline Flexibility to Increase & $\begin{array}{l}\text { Yes, without } \\
\text { restrictions. }\end{array}$ & $\begin{array}{l}\text { Yes, with some } \\
\text { restrictions. }\end{array}$ & \begin{tabular}{|l} 
Yes, with some \\
restrictions and \\
requires ex-post \\
approval of \\
legislature.
\end{tabular} & $\begin{array}{l}\text { Yes, with some } \\
\text { restrictions and } \\
\text { requires prior } \\
\text { approval of } \\
\text { legislature. }\end{array}$ & $\begin{array}{l}\text { Strictly forbidden unless } \\
\text { emergency. Requires prior } \\
\text { approval. }\end{array}$ \\
\hline Sanctions for Poor & No sanctions. & Only moral & Expenditure for & Program may be & Expenditure of entire ministry \\
\hline
\end{tabular}




\begin{tabular}{|c|c|c|c|c|c|}
\hline Performance & & sanctions. & $\begin{array}{l}\text { program may be } \\
\text { reduced. }\end{array}$ & eliminated. & "may be reduced. \\
\hline \multicolumn{6}{|l|}{ Sustainability and Credibility } \\
\hline $\begin{array}{l}\text { Inter-period } \\
\text { transferability of funds }\end{array}$ & Allowed. & $\begin{array}{l}\text { Allowed within } \\
\text { limits but no } \\
\text { approval required. }\end{array}$ & $\begin{array}{l}\text { Allowed with } \\
\text { restrictions and } \\
\text { requires approval } \\
\text { of Legislature. }\end{array}$ & $\begin{array}{l}\text { Allowed with } \\
\text { restrictions and } \\
\text { requires approval of } \\
\text { legislature and } \\
\text { Minister of Finance. }\end{array}$ & Forbidden. \\
\hline $\begin{array}{l}\text { Reallocation of Funds } \\
\text { between Programs and } \\
\text { Units. }\end{array}$ & $\begin{array}{l}\text { Allowed without } \\
\text { limits or generally } \\
\text { forbidden }\end{array}$ & $\begin{array}{l}\text { Allowed without } \\
\text { limits but requires } \\
\text { approval of } \\
\text { legislature or MoF. }\end{array}$ & $\begin{array}{l}\text { Allowed within } \\
\text { restrictions but no } \\
\text { approval required. }\end{array}$ & $\begin{array}{l}\text { Allowed within } \\
\text { restrictions and } \\
\text { requires approval of } \\
\text { legislature or MoF. }\end{array}$ & $\begin{array}{l}\text { Allowed within restrictions and } \\
\text { requires approval of legislature } \\
\text { and Finance Minister. }\end{array}$ \\
\hline \multicolumn{6}{|l|}{ Transparency } \\
\hline In-Year Reports. & No in-year reports. & $\begin{array}{l}\text { Released at least } \\
\text { twice a year but } \\
\text { covers less than two } \\
\text { thirds of } \\
\text { expenditures. }\end{array}$ & $\begin{array}{l}\text { Released twice a } \\
\text { year and covers at } \\
\text { least two thirds of } \\
\text { expenditures. }\end{array}$ & $\begin{array}{l}\text { Released at least } \\
\text { every quarter and } \\
\text { covers at least two } \\
\text { thirds of } \\
\text { expenditures. }\end{array}$ & $\begin{array}{l}\text { Released at least every quarter } \\
\text { and covers all expenditures. }\end{array}$ \\
\hline $\begin{array}{l}\text { Detail of Year-End } \\
\text { Reports }\end{array}$ & $\begin{array}{l}\text { No explanation of } \\
\text { the differences is } \\
\text { provided, or such a } \\
\text { report is not released }\end{array}$ & $\begin{array}{l}\text { The explanation of } \\
\text { differences between } \\
\text { enacted and actual } \\
\text { expenditure levels } \\
\text { focuses on total } \\
\text { budget. }\end{array}$ & $\begin{array}{l}\text { The explanation of } \\
\text { differences } \\
\text { between enacted } \\
\text { and actual } \\
\text { expenditure levels } \\
\text { focuses on total } \\
\text { budget and some } \\
\text { key programs. }\end{array}$ & $\begin{array}{l}\text { The explanation } \\
\text { focuses on } \\
\text { departmental totals } \\
\text { (or functional totals) } \\
\text { or some lower level } \\
\text { of detail (but not the } \\
\text { program level in all } \\
\text { cases). }\end{array}$ & $\begin{array}{l}\text { The explanation of the } \\
\text { differences between the enacted } \\
\text { expenditure levels and the } \\
\text { actual outcome focuses on the } \\
\text { program level. }\end{array}$ \\
\hline $\begin{array}{l}\text { Publication of } \\
\text { Performance Targets }\end{array}$ & $\begin{array}{l}\text { No performance } \\
\text { targets. }\end{array}$ & & $\begin{array}{l}\text { Publication of } \\
\text { performance } \\
\text { targets for a few } \\
\text { key/ priority } \\
\text { sectors. }\end{array}$ & & $\begin{array}{l}\text { Publication of performance } \\
\text { targets for all sectors and } \\
\text { maybe even programs. }\end{array}$ \\
\hline Total Score: & & & & & \\
\hline
\end{tabular}




\section{APPENDIX II: INDEX SCORES UNDER PCA AND GEOMETRIC AgGREGATION}

Table A-II 1: Index Values with Principal Component Analysis

\begin{tabular}{|c|c|c|c|c|c|c|}
\hline COUNTRY & $\begin{array}{l}\text { CENTRA- } \\
\text { LIZATION }\end{array}$ & $\begin{array}{l}\text { RULES \& } \\
\text { CONTROLS }\end{array}$ & $\begin{array}{l}\text { SUSTAINA- } \\
\text { BILITY }\end{array}$ & $\begin{array}{l}\text { COMPREHEN- } \\
\text { SIVE NESS }\end{array}$ & $\begin{array}{l}\text { TRANSPA- } \\
\text { RENCY }\end{array}$ & OVERALL \\
\hline Algeria & 0.598 & 0.288 & 0.174 & 0.315 & 0.358 & 0.346 \\
\hline Angola & 0.684 & 0.483 & 0.428 & 0.548 & 0.814 & 0.591 \\
\hline Benin & 0.842 & 0.617 & 0.458 & 0.439 & 0.658 & 0.603 \\
\hline Botswana & 0.547 & 0.547 & 0.289 & 0.480 & 0.487 & 0.470 \\
\hline Burkina Faso & 0.705 & 0.690 & 0.420 & 0.135 & 0.369 & 0.464 \\
\hline Burundi & 0.804 & 0.488 & 0.409 & 0.159 & 0.235 & 0.419 \\
\hline Cameroon & 0.268 & 0.522 & 0.396 & 0.181 & 0.126 & 0.298 \\
\hline Cape Verde & 0.664 & 0.519 & 0.666 & 0.864 & 0.690 & 0.681 \\
\hline$\overline{\text { CAR }}$ & 0.297 & 0.219 & 0.259 & 0.118 & 0.081 & 0.195 \\
\hline Chad & 0.650 & 0.390 & 0.457 & 0.482 & 0.330 & 0.462 \\
\hline Congo, DR & 0.272 & 0.236 & 0.281 & 0.315 & 0.205 & 0.262 \\
\hline Congo, Rep. & 0.530 & 0.727 & 0.401 & 0.590 & 0.631 & 0.576 \\
\hline CDI & 0.459 & 0.408 & 0.571 & 0.666 & 0.167 & 0.454 \\
\hline Egypt & 0.578 & 0.567 & 0.634 & 0.181 & 0.460 & 0.484 \\
\hline Equ. Guinea & 0.625 & 0.359 & 0.207 & 0.000 & 0.097 & 0.257 \\
\hline Ethiopia & 0.625 & 0.442 & 0.250 & 0.617 & 0.221 & 0.431 \\
\hline Gabon & 0.650 & 0.478 & 0.529 & 0.533 & 0.605 & 0.559 \\
\hline Gambia, The & 0.485 & 0.287 & 0.354 & 0.296 & 0.089 & 0.302 \\
\hline Ghana & 0.864 & 0.522 & 0.571 & 0.607 & 0.319 & 0.577 \\
\hline Kenya & 0.636 & 0.730 & 0.802 & 0.528 & 0.692 & 0.677 \\
\hline Lesotho & 0.850 & 0.345 & 0.481 & 0.410 & 0.520 & 0.521 \\
\hline Liberia & 0.625 & 0.671 & 0.102 & 0.404 & 0.217 & 0.403 \\
\hline Libya & 0.211 & 0.329 & 0.373 & 0.588 & 0.487 & 0.398 \\
\hline Madagascar & 0.791 & 0.613 & 0.599 & 0.728 & 0.392 & 0.625 \\
\hline Malawi & 0.397 & 0.509 & 0.654 & 0.364 & 0.597 & 0.504 \\
\hline Mali & 0.744 & 0.708 & 0.557 & 0.564 & 0.666 & 0.648 \\
\hline Mauritius & 0.671 & 0.542 & 0.624 & 0.439 & 0.316 & 0.518 \\
\hline Morocco & 0.590 & 0.622 & 0.742 & 0.224 & 0.551 & 0.546 \\
\hline Mozambique & 0.419 & 0.733 & 0.445 & 0.729 & 0.324 & 0.530 \\
\hline Namibia & 0.894 & 0.768 & 0.806 & 0.699 & 0.574 & 0.748 \\
\hline Niger & 0.804 & 0.588 & 0.461 & 0.665 & 0.739 & 0.651 \\
\hline Nigeria & 0.684 & 0.635 & 0.724 & 0.180 & 0.592 & 0.563 \\
\hline Rwanda & 0.625 & 0.819 & 0.594 & 0.717 & 0.256 & 0.602 \\
\hline STP & 0.625 & 0.338 & 0.182 & 0.185 & 0.276 & 0.321 \\
\hline Senegal & 0.864 & 0.566 & 0.436 & 0.611 & 0.331 & 0.561 \\
\hline Seychelles & 0.804 & 0.437 & 0.095 & 0.184 & 0.492 & 0.402 \\
\hline Sierra Leone & 0.654 & 0.668 & 0.586 & 0.424 & 0.687 & 0.604 \\
\hline South Africa & 0.578 & 0.466 & 0.832 & 0.563 & 0.841 & 0.656 \\
\hline Sudan & 0.047 & 0.235 & 0.238 & 0.118 & 0.167 & 0.161 \\
\hline Swaziland & 0.727 & 0.364 & 0.317 & 0.256 & 0.391 & 0.411 \\
\hline
\end{tabular}


53

\begin{tabular}{||l|l|l|l|l|r|r||}
\hline Tanzania & 0.625 & 0.610 & 0.545 & 0.755 & 0.757 & 0.658 \\
\hline Togo & 0.735 & 0.525 & 0.629 & 0.954 & 0.569 & 0.682 \\
\hline Tunisia & 0.864 & 0.785 & 0.576 & 0.288 & 0.762 & 0.655 \\
\hline Uganda & 0.280 & 0.214 & 0.744 & 0.784 & 0.763 & 0.557 \\
\hline Zambia & 0.684 & 0.358 & 0.492 & 0.528 & 0.821 & 0.577 \\
\hline Zimbabwe & 0.698 & 0.363 & 0.548 & 0.089 & 0.242 & 0.388 \\
\hline
\end{tabular}


Table A-II 2: Index Values with Geometric Aggregation

\begin{tabular}{|c|c|c|c|c|c|c|}
\hline "COUNTRY & $\begin{array}{l}\text { CENTRA- } \\
\text { LIZATION }\end{array}$ & $\begin{array}{l}\text { RULES \& } \\
\text { CONTROLS }\end{array}$ & $\begin{array}{l}\text { SUSTAINA- } \\
\text { BILITY }\end{array}$ & $\begin{array}{l}\text { COMPREHEN- } \\
\text { SIVENESS }\end{array}$ & $\begin{array}{l}\text { TRANSPA- } \\
\text { RENCY }\end{array}$ & " OVERALL \\
\hline Algeria & 0.780 & 0.623 & 0.576 & 0.625 & 0.649 & 0.114 \\
\hline Angola & 0.819 & 0.728 & 0.701 & 0.738 & 0.883 & 0.273 \\
\hline Benin & 0.906 & 0.785 & 0.709 & 0.697 & 0.797 & 0.280 \\
\hline Botswana & 0.757 & 0.748 & 0.628 & 0.707 & 0.705 & 0.177 \\
\hline $\begin{array}{l}\text { Burkina } \\
\text { Faso }\end{array}$ & 0.826 & 0.823 & 0.683 & 0.557 & 0.654 & 0.169 \\
\hline Burundi & 0.888 & 0.728 & 0.685 & 0.571 & 0.594 & 0.150 \\
\hline Cameroon & 0.622 & 0.733 & 0.662 & 0.576 & 0.555 & 0.096 \\
\hline Cape Verde & 0.802 & 0.745 & 0.823 & 0.930 & 0.827 & 0.378 \\
\hline$\overline{\text { CAR }}$ & 0.617 & 0.603 & 0.604 & 0.549 & 0.535 & 0.066 \\
\hline Chad & 0.792 & 0.668 & 0.701 & 0.712 & 0.643 & 0.170 \\
\hline Congo, DR & 0.616 & 0.610 & 0.619 & 0.625 & 0.594 & 0.086 \\
\hline Congo, Rep. & 0.734 & 0.838 & 0.676 & 0.764 & 0.790 & 0.251 \\
\hline CDI & 0.703 & 0.670 & 0.755 & 0.799 & 0.561 & 0.159 \\
\hline Egypt & 0.755 & 0.769 & 0.794 & 0.576 & 0.693 & 0.184 \\
\hline Equ. Guinea & 0.777 & 0.650 & 0.591 & 0.500 & 0.541 & 0.081 \\
\hline Ethiopia & 0.777 & 0.704 & 0.595 & 0.787 & 0.593 & 0.152 \\
\hline Gabon & 0.792 & 0.714 & 0.744 & 0.733 & 0.760 & 0.234 \\
\hline Gambia, The & 0.700 & 0.618 & 0.658 & 0.633 & 0.538 & 0.097 \\
\hline Ghana & 0.916 & 0.727 & 0.760 & 0.772 & 0.624 & 0.244 \\
\hline Kenya & 0.777 & 0.835 & 0.891 & 0.727 & 0.833 & 0.350 \\
\hline Lesotho & 0.910 & 0.658 & 0.716 & 0.672 & 0.727 & 0.209 \\
\hline Liberia & 0.777 & 0.829 & 0.544 & 0.666 & 0.584 & 0.136 \\
\hline Libya & 0.579 & 0.648 & 0.665 & 0.769 & 0.709 & 0.136 \\
\hline Madagascar & 0.877 & 0.788 & 0.769 & 0.834 & 0.680 & 0.302 \\
\hline Malawi & 0.658 & 0.728 & 0.800 & 0.654 & 0.768 & 0.192 \\
\hline Mali & 0.856 & 0.839 & 0.761 & 0.752 & 0.815 & 0.335 \\
\hline Mauritius & 0.796 & 0.748 & 0.786 & 0.683 & 0.647 & 0.207 \\
\hline Morocco & 0.758 & 0.790 & 0.856 & 0.593 & 0.756 & 0.230 \\
\hline Mozambique & 0.683 & 0.865 & 0.707 & 0.840 & 0.631 & 0.221 \\
\hline Namibia & 0.945 & 0.868 & 0.897 & 0.821 & 0.757 & 0.457 \\
\hline Niger & 0.888 & 0.762 & 0.704 & 0.799 & 0.846 & 0.322 \\
\hline Nigeria & 0.819 & 0.807 & 0.856 & 0.575 & 0.755 & 0.246 \\
\hline Rwanda & 0.777 & 0.890 & 0.784 & 0.844 & 0.599 & 0.274 \\
\hline STP & 0.777 & 0.658 & 0.570 & 0.584 & 0.625 & 0.106 \\
\hline Senegal & 0.916 & 0.761 & 0.704 & 0.781 & 0.635 & 0.243 \\
\hline Seychelles & 0.888 & 0.688 & 0.544 & 0.568 & 0.711 & 0.134 \\
\hline Sierra Leone & 0.811 & 0.805 & 0.786 & 0.680 & 0.812 & 0.283 \\
\hline South Africa & 0.755 & 0.709 & 0.914 & 0.747 & 0.913 & 0.334 \\
\hline Sudan & 0.521 & 0.608 & 0.598 & 0.543 & 0.561 & 0.058 \\
\hline Swaziland & 0.847 & 0.659 & 0.647 & 0.609 & 0.674 & 0.148 \\
\hline Tanzania & 0.777 & 0.794 & 0.767 & 0.854 & 0.864 & 0.349 \\
\hline Togo & 0.852 & 0.748 & 0.809 & 0.976 & 0.749 & 0.377 \\
\hline Tunisia & 0.916 & 0.875 & 0.777 & 0.620 & 0.855 & 0.330 \\
\hline Uganda & 0.615 & 0.589 & 0.865 & 0.867 & 0.866 & 0.236 \\
\hline Zambia & 0.819 & 0.658 & 0.738 & 0.736 & 0.897 & 0.263 \\
\hline Zimbabwe & 0.831 & 0.660 & 0.736 & 0.534 & 0.602 & 0.130 \\
\hline
\end{tabular}




\section{APPENDIX III: DESCRIPTION OF VARIABLES}

Aid: Average Net official development assistance and official aid received as ratio to GDP between 2003 and 2007. Source WDI 2009

CGPB: average of the central government primary balance as ratio of GDP between 2003 and 2007. Source: IMF WEO 2009.

Corruption: Average of Control of Corruption between 2003 and 2007. Source: World Bank Governance Indicators 2009. Scaled to range between -1 and 1 instead of -2.5 to 2.5

Fractionalization: Average index of fractionalization in ethnicity, language and religion. Source: Alesina et al. 2002. Note: the data is old (sometimes dating back to 1986). But it is reasonable to assume that fractionalization has not changed very much over the past two decades.

GDPPC_2002: In of GDP per capita in constant 2005 International Dollars in PPP terms in 2002. Source: IMF WEO 2009.

Growth: average of annual GDP (constant prices) growth between 2003 and 2007. Source: IMF WEO 2009.

HIPCC: a dummy for the countries that reached the HIPC completion point before 2007. Source: IMF: www.imf.org/external/np/exr/facts/hipc.htm

PED: Average public and publicly guaranteed external debt as ratio of GDP between 2003 and 2007. Source: IMF WEO 2009.

PED_DIFF: Difference between average public and publicly guaranteed external debt as ratio of GDP in 1990 and 2000. Source: IMF WEO 2009.

PRGF: A dummy variable for the existence of a poverty reduction and growth facility in the country between 2000 and 2007. Source: IMF.

Resources: A dummy for countries classified as hydrocarbon- and/or mineral-rich countries between 2000-2005 by the IMF Guide on Resource Revenue Transparency, 2007.

Stability: Stability of political system (only available for 2009 but constructed in a way that it should be representative for recent past). Source: Institutional Profiles Database 2009. Scaled to range between 0 and 1 instead of between 1 and 4

Trade: average the product of annual growth in net barter terms of trade and the degree of openness of the economy (ratio of trade to GDP) between 2003 and 2007. Source IMF WEO 2009.

XCONST: Average of Constraints on the Executive between 2003 and 2007. Source: Polity IV 2008. Scaled to range from 0 o 1 instead of 1 to 7 . 
APPENDIX IV: REgRESSION RESULTS FOR PCA VERSION OF INDEX

Table A-IV 1: Public External Debt with Principal Component Analysis Index

\begin{tabular}{|c|c|c|c|c|c|c|c|}
\hline & "WITHOUT BI & "WITH BI & "CENTRALIZATION & "RULES & " SUSTAINAB'Y & "COMPREHENSIV'S & "TRANSPARENCY \\
\hline VARIABLES & ped & ped & ped & ped & ped & ped & ped \\
\hline \multirow[t]{2}{*}{ Growth } & -1.838 & -0.998 & -1.409 & -1.669 & -1.310 & -1.624 & -1.044 \\
\hline & $(1.557)$ & $(1.665)$ & $(1.481)$ & $(1.665)$ & (1.644) & $(1.721)$ & $(1.647)$ \\
\hline \multirow[t]{2}{*}{ gdppc_2002 } & $-0.279 * * *$ & $-0.244 * * *$ & $-0.236 * * *$ & $-0.265 * * *$ & $-0.261 * * *$ & $-0.276 * * *$ & $-0.255 * * *$ \\
\hline & $(0.0679)$ & $(0.0626)$ & $(0.0648)$ & $(0.0713)$ & $(0.0647)$ & $(0.0654)$ & $(0.0650)$ \\
\hline \multirow[t]{2}{*}{ Trade } & 1.446 & 1.262 & 1.793 & 1.320 & 0.844 & 1.475 & 1.447 \\
\hline & $(1.229)$ & $(1.110)$ & $(1.174)$ & $(1.247)$ & $(1.218)$ & $(1.199)$ & $(1.187)$ \\
\hline \multirow[t]{2}{*}{ Resources } & 0.170 & 0.137 & 0.118 & 0.169 & 0.155 & 0.150 & 0.164 \\
\hline & $(0.151)$ & $(0.155)$ & $(0.154)$ & $(0.155)$ & $(0.153)$ & $(0.148)$ & $(0.156)$ \\
\hline \multirow[t]{2}{*}{ Hipcc } & -0.118 & -0.0681 & -0.0225 & -0.0792 & -0.137 & -0.104 & -0.111 \\
\hline & $(0.104)$ & $(0.104)$ & $(0.115)$ & $(0.123)$ & $(0.101)$ & $(0.108)$ & $(0.101)$ \\
\hline \multirow[t]{2}{*}{ Fractionalization } & -0.321 & -0.277 & -0.432 & -0.331 & -0.243 & -0.273 & -0.290 \\
\hline & $(0.255)$ & $(0.287)$ & $(0.268)$ & $(0.278)$ & $(0.271)$ & $(0.257)$ & $(0.282)$ \\
\hline \multirow[t]{2}{*}{ index_pca } & & $-0.636^{*}$ & & & & & \\
\hline & & $(0.350)$ & & & & & \\
\hline \multirow[t]{2}{*}{ centralization_pca } & & & $-0.639 * *$ & & & & \\
\hline & & & $(0.235)$ & & & & \\
\hline \multirow[t]{2}{*}{ rules_pca } & & & & -0.198 & & & \\
\hline & & & & $(0.369)$ & & & \\
\hline \multirow[t]{2}{*}{ sustainability_pca } & & & & & -0.396 & & \\
\hline & & & & & $(0.250)$ & & \\
\hline \multirow[t]{2}{*}{ comprehensiveness_pca } & & & & & & -0.180 & \\
\hline & & & & & & $(0.228)$ & \\
\hline \multirow[t]{2}{*}{ transparency_pca } & & & & & & & -0.310 \\
\hline & & & & & & & $(0.224)$ \\
\hline \multirow[t]{2}{*}{ Constant } & $2.814 * * *$ & $2.807 * * *$ & $2.908 * * *$ & $2.797 * * *$ & $2.828 * * *$ & $2.839 * * *$ & $2.722 * * *$ \\
\hline & $(0.627)$ & $(0.566)$ & $(0.557)$ & $(0.622)$ & $(0.591)$ & $(0.615)$ & $(0.594)$ \\
\hline Observations & 40 & 40 & 40 & 40 & 40 & 40 & 40 \\
\hline R-squared & 0.392 & 0.451 & 0.492 & 0.399 & 0.426 & 0.405 & 0.430 \\
\hline
\end{tabular}

Robust standard errors in parentheses; $* * * p<0.01, * * p<0.05, * p<0.1$ 
Table A-IV 2: Central Government Primary Balance with Principal Component Analysis Budget Institutions

\begin{tabular}{|c|c|c|c|c|c|c|c|}
\hline & $\begin{array}{c}\text { WITHOUT } \\
\text { BI }\end{array}$ & WITH BI & CENTRALIZATION & RULES & SUSTAINAB'Y & COMPREHENSIV'S & TRANSPARENCY \\
\hline VARIABLES & cgpb & cgpb & cgpb & cgpb & cgpb & cgpb & cgpb \\
\hline \multirow[t]{2}{*}{ Growth } & $-0.455^{*}$ & $-0.512 * *$ & $-0.471 * *$ & $-0.481 * *$ & $-0.467 *$ & $-0.457 *$ & $-0.569 * *$ \\
\hline & $(0.226)$ & $(0.250)$ & $(0.230)$ & $(0.233)$ & $(0.242)$ & $(0.236)$ & $(0.256)$ \\
\hline \multirow[t]{2}{*}{ gdppc_2002 } & -0.00232 & -0.00391 & -0.00311 & -0.00311 & -0.00281 & -0.00231 & -0.00551 \\
\hline & $(0.00825)$ & $(0.00816)$ & $(0.00834)$ & $(0.00792)$ & $(0.00856)$ & $(0.00835)$ & $(0.00798)$ \\
\hline \multirow[t]{2}{*}{ Trade } & $0.222 *$ & $0.241^{*}$ & $0.216^{*}$ & $0.255^{*}$ & $0.234^{*}$ & $0.222 *$ & $0.224 *$ \\
\hline & $(0.113)$ & $(0.121)$ & $(0.114)$ & $(0.128)$ & $(0.129)$ & $(0.115)$ & $(0.116)$ \\
\hline \multirow[t]{2}{*}{ Resources } & $0.0414 * *$ & $0.0435^{* *}$ & $0.0433^{* *}$ & $0.0413^{* *}$ & $0.0418^{* *}$ & $0.0416^{* *}$ & $0.0423^{* *}$ \\
\hline & $(0.0164)$ & $(0.0163)$ & $(0.0169)$ & $(0.0166)$ & $(0.0165)$ & $(0.0168)$ & $(0.0156)$ \\
\hline \multirow[t]{2}{*}{ Fractionalization } & -0.00773 & -0.00955 & -0.00201 & -0.00402 & -0.00957 & -0.00813 & -0.0119 \\
\hline & $(0.0320)$ & $(0.0329)$ & $(0.0319)$ & $(0.0357)$ & $(0.0332)$ & $(0.0331)$ & $(0.0335)$ \\
\hline \multirow[t]{2}{*}{ index_pca } & & 0.0435 & & & & & \\
\hline & & $(0.0454)$ & & & & & \\
\hline \multirow[t]{2}{*}{ centralization_pca } & & & 0.0254 & & & & \\
\hline & & & $(0.0407)$ & & & & \\
\hline \multirow[t]{2}{*}{ rules_pca } & & & & 0.0317 & & & \\
\hline & & & & $(0.0391)$ & & & \\
\hline \multirow{2}{*}{ sustainability_pca } & & & & & 0.00857 & & \\
\hline & & & & & $(0.0327)$ & & \\
\hline \multirow[t]{2}{*}{ comprehensiveness_pca } & & & & & & 0.00165 & \\
\hline & & & & & & $(0.0256)$ & \\
\hline \multirow[t]{2}{*}{ transparency_pca } & & & & & & & 0.0445 \\
\hline & & & & & & & $(0.0265)$ \\
\hline \multirow[t]{2}{*}{ Constant } & 0.0526 & 0.0448 & 0.0397 & 0.0404 & 0.0532 & 0.0520 & 0.0633 \\
\hline & $(0.0808)$ & $(0.0782)$ & $(0.0770)$ & $(0.0845)$ & $(0.0819)$ & $(0.0817)$ & $(0.0771)$ \\
\hline Observations & 40 & 40 & 40 & 40 & 40 & 40 & 40 \\
\hline R-squared & 0.376 & 0.393 & 0.386 & 0.389 & 0.377 & 0.376 & 0.422 \\
\hline
\end{tabular}

Robust standard errors in parentheses; *** $p<0.01, * * p<0.05, * p<0$ 


\section{APPENDIX V: CAVEATS AND RobUSTNESS CheCKS}

Table A-V 1: Index Values with Aggregation across Phases

\begin{tabular}{|c|c|c|c|c|}
\hline COUNTRY & "PHASE 1 & "PHASE 2 & "PHASE 3 & "OVERALL \\
\hline Algeria & 0.404 & 0.300 & 0.229 & 0.311 \\
\hline Angola & 0.667 & 0.650 & 0.427 & 0.581 \\
\hline Benin & 0.683 & 0.375 & 0.698 & 0.585 \\
\hline Botswana & 0.604 & 0.125 & 0.573 & 0.434 \\
\hline Burkina Faso & 0.421 & 0.425 & 0.531 & 0.459 \\
\hline Burundi & 0.329 & 0.450 & 0.490 & 0.423 \\
\hline Cameroon & 0.375 & 0.250 & 0.375 & 0.333 \\
\hline Cape Verde & 0.758 & 0.400 & 0.833 & 0.664 \\
\hline CAR & 0.038 & 0.250 & 0.417 & 0.235 \\
\hline Chad & 0.279 & 0.625 & 0.490 & 0.465 \\
\hline Congo, DR & 0.167 & 0.325 & 0.208 & 0.233 \\
\hline Congo, Rep. & 0.575 & 0.600 & 0.458 & 0.544 \\
\hline CDI & 0.521 & 0.375 & 0.313 & 0.403 \\
\hline Egypt & 0.429 & 0.400 & 0.688 & 0.506 \\
\hline Equ. Guinea & 0.454 & 0.050 & 0.313 & 0.272 \\
\hline Ethiopia & 0.479 & 0.325 & 0.542 & 0.449 \\
\hline Gabon & 0.450 & 0.825 & 0.479 & 0.585 \\
\hline Gambia, The & 0.254 & 0.175 & 0.417 & 0.282 \\
\hline Ghana & 0.704 & 0.450 & 0.531 & 0.562 \\
\hline Kenya & 0.842 & 0.575 & 0.500 & 0.639 \\
\hline Lesotho & 0.492 & 0.500 & 0.594 & 0.528 \\
\hline Liberia & 0.442 & 0.300 & 0.500 & 0.414 \\
\hline Libya & 0.379 & 0.563 & 0.240 & 0.394 \\
\hline Madagascar & 0.658 & 0.525 & 0.656 & 0.613 \\
\hline Malawi & 0.775 & 0.125 & 0.615 & 0.505 \\
\hline Mali & 0.717 & 0.550 & 0.615 & 0.627 \\
\hline Mauritius & 0.658 & 0.350 & 0.656 & 0.555 \\
\hline Morocco & 0.658 & 0.625 & 0.354 & 0.546 \\
\hline Mozambique & 0.596 & 0.475 & 0.521 & 0.531 \\
\hline Namibia & 0.854 & 0.575 & 0.927 & 0.785 \\
\hline Niger & 0.733 & 0.575 & 0.583 & 0.631 \\
\hline Nigeria & 0.621 & 0.550 & 0.635 & 0.602 \\
\hline Rwanda & 0.729 & 0.325 & 0.667 & 0.574 \\
\hline STP & 0.288 & 0.225 & 0.542 & 0.351 \\
\hline Senegal & 0.488 & 0.625 & 0.552 & 0.555 \\
\hline Seychelles & 0.417 & 0.350 & 0.396 & 0.388 \\
\hline Sierra Leone & 0.679 & 0.650 & 0.625 & 0.651 \\
\hline South Africa & 0.579 & 0.600 & 0.927 & 0.702 \\
\hline Sudan & 0.092 & 0.250 & 0.156 & 0.166 \\
\hline Swaziland & 0.367 & 0.375 & 0.615 & 0.452 \\
\hline
\end{tabular}




\begin{tabular}{||l|r|r|r|r||}
\hline \hline Tanzania & 0.725 & 0.625 & 0.573 & 0.641 \\
\hline Togo & 0.829 & 0.575 & 0.552 & 0.652 \\
\hline Tunisia & 0.625 & 0.725 & 0.594 & 0.648 \\
\hline Uganda & 0.558 & 0.575 & 0.479 & 0.538 \\
\hline Zambia & 0.658 & 0.475 & 0.573 & 0.569 \\
\hline Zimbabwe & 0.321 & 0.350 & 0.604 & 0.425 \\
\hline
\end{tabular}

Table A-V 2: Public External Debt with Index_Phase

\begin{tabular}{||l|c|c|c|c|c||}
\hline & $\begin{array}{c}\text { WITHOUT } \\
\text { BI }\end{array}$ & WITH BI_PHASES & $\begin{array}{c}\text { WITH } \\
\text { PHASE1 }\end{array}$ & $\begin{array}{c}\text { WITH } \\
\text { PHASE2 }\end{array}$ & $\begin{array}{c}\text { WITH } \\
\text { PHASE3 }\end{array}$ \\
\hline VARIABLES & ped & ped & ped & ped & ped \\
\hline growth & -1.838 & -0.891 & -1.215 & -1.443 & -1.316 \\
\hline & $(1.557)$ & $(1.622)$ & $(1.659)$ & $(1.778)$ & $(1.558)$ \\
\hline gdppc_2002 & $-0.279^{* * *}$ & $-0.235^{* * *}$ & $-0.249 * *$ & $-0.268^{* * *}$ & $-0.239^{* * *}$ \\
\hline & $(0.0679)$ & $(0.0658)$ & $(0.0592)$ & $(0.0697)$ & $(0.0660)$ \\
\hline trade & 1.446 & 1.234 & 1.205 & 1.467 & 1.189 \\
\hline & $(1.229)$ & $(1.092)$ & $(1.128)$ & $(1.221)$ & $(1.141)$ \\
\hline resources & 0.170 & 0.138 & 0.155 & 0.160 & 0.139 \\
\hline & $(0.151)$ & $(0.159)$ & $(0.148)$ & $(0.162)$ & $(0.154)$ \\
\hline hipcc & -0.118 & -0.0599 & -0.0532 & -0.115 & -0.0665 \\
\hline & $(0.104)$ & $(0.101)$ & $(0.103)$ & $(0.103)$ & $(0.102)$ \\
\hline fractionalization & -0.321 & -0.259 & -0.301 & -0.284 & -0.288 \\
\hline & $(0.255)$ & $(0.297)$ & $(0.264)$ & $(0.289)$ & $(0.282)$ \\
\hline BI_phases & & $-0.683 *$ & & & \\
\hline & & $(0.372)$ & & & \\
\hline phase1 & & & $-0.448^{* *}$ & & $(0.219)$ \\
\hline
\end{tabular}

Robust standard errors in parentheses $* * * p<0.01, * * p<0.05, * p<0.1$ 
Table A-V 3: Central Government Primary Balance with Index_Phase

\begin{tabular}{|c|c|c|c|c|c|}
\hline & $\begin{array}{c}\text { WITHOUT } \\
\text { BI }\end{array}$ & $\begin{array}{c}\text { WITH } \\
\text { BI_PHASES }\end{array}$ & $\begin{array}{c}\text { WITH } \\
\text { PHASE1 }\end{array}$ & $\begin{array}{c}\text { WITH } \\
\text { PHASE2 }\end{array}$ & $\begin{array}{c}\text { WITH } \\
\text { PHASE3 }\end{array}$ \\
\hline VARIABLES & cgpb & cgpb & cgpb & cgpb & cgpb \\
\hline \multirow[t]{2}{*}{ growth } & $-0.455^{*}$ & $-0.511 *$ & $-0.492 *$ & $-0.546 * *$ & $-0.449 *$ \\
\hline & $(0.226)$ & $(0.253)$ & $(0.246)$ & $(0.239)$ & $(0.233)$ \\
\hline \multirow[t]{2}{*}{ gdppc_2002 } & -0.00232 & -0.00411 & -0.00318 & -0.00471 & -0.00198 \\
\hline & $(0.00825)$ & $(0.00818)$ & $(0.00820)$ & $(0.00776)$ & $(0.00857)$ \\
\hline \multirow[t]{2}{*}{ trade } & $0.222 *$ & $0.242^{*}$ & $0.244^{*}$ & $0.218^{*}$ & $0.217 *$ \\
\hline & $(0.113)$ & $(0.122)$ & $(0.121)$ & $(0.115)$ & $(0.120)$ \\
\hline \multirow[t]{2}{*}{ resources } & $0.0414 * *$ & $0.0432 * *$ & $0.0421 * *$ & $0.0437 * * *$ & $0.0410 * *$ \\
\hline & $(0.0164)$ & $(0.0161)$ & $(0.0164)$ & $(0.0159)$ & $(0.0161)$ \\
\hline \multirow[t]{2}{*}{ fractionalization } & -0.00773 & -0.0103 & -0.00758 & -0.0160 & -0.00754 \\
\hline & $(0.0320)$ & $(0.0329)$ & $(0.0329)$ & $(0.0321)$ & $(0.0321)$ \\
\hline \multirow[t]{2}{*}{ BI_phases } & & 0.0411 & & & \\
\hline & & $(0.0463)$ & & & \\
\hline \multirow[t]{2}{*}{ phase1 } & & & 0.0268 & & \\
\hline & & & $(0.0303)$ & & \\
\hline \multirow[t]{2}{*}{ phase2 } & & & & 0.0515 & \\
\hline & & & & $(0.0355)$ & \\
\hline \multirow[t]{2}{*}{ phase3 } & & & & & -0.00658 \\
\hline & & & & & $(0.0388)$ \\
\hline \multirow[t]{2}{*}{ Constant } & 0.0526 & 0.0482 & 0.0453 & 0.0560 & 0.0533 \\
\hline & $(0.0808)$ & $(0.0785)$ & $(0.0787)$ & $(0.0749)$ & $(0.0824)$ \\
\hline Observations & 40 & 40 & 40 & 40 & 40 \\
\hline R-squared & 0.376 & 0.391 & 0.390 & 0.411 & 0.376 \\
\hline
\end{tabular}

Robust standard errors in parentheses $* * * p<0.01, * * p<0.05, * p<0.1$ 
Table A-V 4: Public External Debt with Corruption

\begin{tabular}{|c|c|c|c|c|c|c|c|}
\hline & $\begin{array}{c}\text { WITHOUT } \\
\text { BI }\end{array}$ & $\begin{array}{c}\text { WITH } \\
\text { BI }\end{array}$ & CENTRALIZATION & RULES & S"SUSTAINAB'Y & COMPREHENSIV'S & TRANSPARENCY \\
\hline VARIABLES & ped & ped & ped & ped & ped & ped & ped \\
\hline \multirow[t]{2}{*}{ Growth } & -1.773 & -0.910 & -1.076 & -1.576 & -1.584 & -1.436 & -1.027 \\
\hline & $(1.601)$ & $(1.729)$ & $(1.550)$ & $(1.713)$ & $(1.689)$ & $(1.797)$ & $(1.704)$ \\
\hline \multirow[t]{2}{*}{ gdppc_2002 } & $-0.247 * * *$ & $\begin{array}{c}- \\
0.234 * * *\end{array}$ & $-0.236^{* * *}$ & $-0.232 * * *$ & $-0.247 * * *$ & $-0.254 * * *$ & $-0.231 * * *$ \\
\hline & $(0.0799)$ & $(0.0737)$ & $(0.0771)$ & $(0.0810)$ & $(0.0763)$ & $(0.0827)$ & $(0.0750)$ \\
\hline \multirow[t]{2}{*}{ Trade } & 1.237 & 1.223 & 1.757 & 1.107 & 0.856 & 1.342 & 1.281 \\
\hline & $(1.320)$ & $(1.196)$ & $(1.312)$ & $(1.321)$ & $(1.243)$ & $(1.318)$ & $(1.291)$ \\
\hline \multirow[t]{2}{*}{ Resources } & 0.166 & 0.140 & 0.114 & 0.165 & 0.162 & 0.151 & 0.159 \\
\hline & $(0.151)$ & $(0.160)$ & $(0.158)$ & $(0.156)$ & $(0.153)$ & $(0.154)$ & $(0.158)$ \\
\hline \multirow[t]{2}{*}{ Hipcc } & -0.0924 & -0.0611 & -0.0471 & -0.0488 & -0.118 & -0.0847 & -0.0878 \\
\hline & $(0.116)$ & $(0.110)$ & $(0.115)$ & $(0.127)$ & $(0.119)$ & $(0.115)$ & $(0.114)$ \\
\hline \multirow[t]{2}{*}{ Fractionalization } & -0.410 & -0.289 & -0.407 & -0.404 & -0.322 & -0.322 & -0.341 \\
\hline & $(0.300)$ & $(0.351)$ & $(0.318)$ & $(0.323)$ & $(0.326)$ & $(0.332)$ & $(0.343)$ \\
\hline \multirow[t]{2}{*}{ Corruption } & -0.234 & -0.0649 & -0.0152 & -0.213 & -0.144 & -0.156 & -0.172 \\
\hline & $(0.269)$ & $(0.343)$ & $(0.319)$ & $(0.282)$ & $(0.313)$ & $(0.325)$ & $(0.294)$ \\
\hline \multirow[t]{2}{*}{ Index } & & -0.604 & & & & & \\
\hline & & $(0.429)$ & & & & & \\
\hline \multirow[t]{2}{*}{ Centralization } & & & $-0.551 * *$ & & & & \\
\hline & & & $(0.259)$ & & & & \\
\hline \multirow[t]{2}{*}{ Rules } & & & & -0.220 & & & \\
\hline & & & & $(0.384)$ & & & \\
\hline \multirow[t]{2}{*}{ Sustainability } & & & & & -0.326 & & \\
\hline & & & & & $(0.275)$ & & \\
\hline \multirow[t]{2}{*}{ comprehensiveness } & & & & & & -0.192 & \\
\hline & & & & & & $(0.279)$ & \\
\hline \multirow[t]{2}{*}{ Transparency } & & & & & & & -0.281 \\
\hline & & & & & & & $(0.246)$ \\
\hline \multirow[t]{2}{*}{ Constant } & $2.570 * * *$ & $2.700 * * *$ & $2.808 * * *$ & $2.552 * * *$ & $2.719 * * *$ & $2.664 * * *$ & $2.510 * * *$ \\
\hline & $(0.693)$ & $(0.663)$ & $(0.688)$ & $(0.679)$ & $(0.688)$ & $(0.729)$ & $(0.657)$ \\
\hline Observations & 40 & 40 & 40 & 40 & 40 & 40 & 40 \\
\hline R-squared & 0.403 & 0.453 & 0.472 & 0.411 & 0.427 & 0.416 & 0.432 \\
\hline
\end{tabular}


Table A-V 5: Central Government Primary Balance with Corruption

\begin{tabular}{|c|c|c|c|c|c|c|c|}
\hline & $\begin{array}{c}\text { WITHOUT } \\
\text { BI }\end{array}$ & WITH BI & CENTRALIZATION & RULES & SUSTAINAB'Y & COMPREHENSIV'S & TRANSPARENCY \\
\hline VARIABLES & cgpb & cgpb & cgpb & cgpb & cgpb & cgpb & cgpb \\
\hline \multirow[t]{2}{*}{ Growth } & $-0.443 * *$ & $-0.535 * *$ & $-0.485^{* *}$ & $-0.469 * *$ & $-0.461 * *$ & $-0.462 * *$ & $-0.595 * *$ \\
\hline & $(0.204)$ & $(0.219)$ & $(0.214)$ & $(0.205)$ & $(0.213)$ & $(0.211)$ & $(0.221)$ \\
\hline \multirow[t]{2}{*}{ gdppc_2002 } & 0.00304 & 0.00275 & 0.00327 & 0.00291 & 0.00237 & 0.00417 & $8.12 \mathrm{e}-05$ \\
\hline & $(0.0102)$ & $(0.00963)$ & $(0.00984)$ & $(0.0102)$ & $(0.0102)$ & $(0.0104)$ & $(0.00955)$ \\
\hline \multirow[t]{2}{*}{ Trade } & 0.169 & 0.174 & 0.140 & 0.195 & 0.199 & 0.157 & 0.161 \\
\hline & $(0.124)$ & $(0.127)$ & $(0.116)$ & $(0.134)$ & $(0.139)$ & $(0.126)$ & $(0.128)$ \\
\hline \multirow[t]{2}{*}{ Resources } & $0.0408 * *$ & $0.0434 * * *$ & $0.0438 * * *$ & $0.0405 * *$ & $0.0413 * *$ & $0.0427 * *$ & $0.0423 * * *$ \\
\hline & $(0.0158)$ & $(0.0145)$ & $(0.0152)$ & $(0.0156)$ & $(0.0156)$ & $(0.0156)$ & $(0.0140)$ \\
\hline \multirow[t]{2}{*}{ Fractionalization } & -0.0276 & -0.0404 & -0.0276 & -0.0281 & -0.0354 & -0.0361 & -0.0414 \\
\hline & $(0.0323)$ & $(0.0304)$ & $(0.0307)$ & $(0.0334)$ & $(0.0330)$ & $(0.0311)$ & $(0.0328)$ \\
\hline \multirow[t]{2}{*}{ Corruption } & -0.0479 & -0.0687 & $-0.0634 *$ & -0.0556 & -0.0543 & -0.0577 & -0.0613 \\
\hline & $(0.0409)$ & $(0.0411)$ & $(0.0354)$ & $(0.0422)$ & $(0.0419)$ & $(0.0424)$ & $(0.0391)$ \\
\hline \multirow[t]{2}{*}{ Index } & & 0.0651 & & & & & \\
\hline & & $(0.0432)$ & & & & & \\
\hline \multirow[t]{2}{*}{ Centralization } & & & 0.0337 & & & & \\
\hline & & & $(0.0368)$ & & & & \\
\hline \multirow[t]{2}{*}{ Rules } & & & & 0.0317 & & & \\
\hline & & & & $(0.0369)$ & & & \\
\hline \multirow[t]{2}{*}{ Sustainability } & & & & & 0.0288 & & \\
\hline & & & & & $(0.0288)$ & & \\
\hline \multirow[t]{2}{*}{ comprehensiveness_pca } & & & & & & 0.0181 & \\
\hline & & & & & & $(0.0268)$ & \\
\hline \multirow[t]{2}{*}{ Transparency } & & & & & & & $0.0574 * *$ \\
\hline & & & & & & & $(0.0250)$ \\
\hline \multirow[t]{2}{*}{ Constant } & 0.0151 & -0.00900 & -0.00771 & -0.00101 & 0.00860 & 0.00174 & 0.0246 \\
\hline & $(0.0919)$ & $(0.0874)$ & $(0.0859)$ & $(0.101)$ & $(0.0902)$ & $(0.0948)$ & $(0.0850)$ \\
\hline Observations & 40 & 40 & 40 & 40 & 40 & 40 & 40 \\
\hline R-squared & 0.404 & 0.440 & 0.421 & 0.418 & 0.416 & 0.411 & 0.479 \\
\hline
\end{tabular}


Table A-V 6: Public External Debt with IMF Programs

\begin{tabular}{|c|c|c|c|c|c|c|c|}
\hline & WITHOUT BI & WITH BI & $\begin{array}{c}\text { CENTRALIZ } \\
\text { ATION }\end{array}$ & RULES & $\begin{array}{c}\text { SUSTAINAB' } \\
\text { Y }\end{array}$ & $\begin{array}{l}\text { COMPREHE } \\
\text { NSIV'S }\end{array}$ & $\begin{array}{c}\text { TRANSPAREN } \\
\text { CY }\end{array}$ \\
\hline VARIABLES & ped & ped & ped & ped & ped & ped & ped \\
\hline \multirow[t]{2}{*}{ Growth } & -1.456 & -0.504 & -0.556 & -1.310 & -1.195 & -1.072 & -0.584 \\
\hline & $(1.596)$ & $(1.760)$ & $(1.510)$ & $(1.746)$ & $(1.754)$ & $(1.730)$ & $(1.775)$ \\
\hline \multirow[t]{2}{*}{ gdppc_2002 } & $-0.238 * * *$ & $-0.200 * * *$ & $-0.185 * *$ & $-0.226^{* * *}$ & $-0.223 * * *$ & $-0.236^{* * *}$ & $-0.209 * *$ \\
\hline & $(0.0773)$ & $(0.0727)$ & $(0.0732)$ & $(0.0806)$ & $(0.0722)$ & $(0.0735)$ & $(0.0788)$ \\
\hline \multirow[t]{2}{*}{ Trade } & 1.415 & 1.243 & 1.756 & 1.286 & 0.891 & 1.455 & 1.401 \\
\hline & $(1.218)$ & $(1.094)$ & $(1.147)$ & $(1.245)$ & $(1.206)$ & $(1.164)$ & $(1.175)$ \\
\hline \multirow[t]{2}{*}{ Resources } & 0.195 & 0.165 & 0.141 & 0.192 & 0.190 & 0.175 & 0.188 \\
\hline & $(0.150)$ & $(0.157)$ & $(0.152)$ & $(0.156)$ & $(0.152)$ & $(0.150)$ & $(0.159)$ \\
\hline \multirow[t]{2}{*}{ Hipcc } & -0.150 & -0.0985 & -0.0831 & -0.106 & -0.169 & -0.130 & -0.139 \\
\hline & $(0.106)$ & $(0.0999)$ & $(0.106)$ & $(0.113)$ & $(0.106)$ & $(0.107)$ & $(0.0989)$ \\
\hline \multirow[t]{2}{*}{ Fractionalization } & -0.355 & -0.296 & -0.449 & -0.354 & -0.296 & -0.288 & -0.307 \\
\hline & $(0.261)$ & $(0.296)$ & $(0.283)$ & $(0.279)$ & $(0.276)$ & $(0.272)$ & $(0.293)$ \\
\hline \multirow[t]{2}{*}{ Prgf } & 0.146 & 0.148 & 0.179 & 0.133 & 0.153 & 0.140 & 0.156 \\
\hline & $(0.138)$ & $(0.109)$ & $(0.119)$ & $(0.126)$ & $(0.122)$ & $(0.128)$ & $(0.122)$ \\
\hline \multirow[t]{2}{*}{ Index } & & $-0.630^{*}$ & & & & & \\
\hline & & $(0.354)$ & & & & & \\
\hline \multirow[t]{2}{*}{ Centralization } & & & $-0.592 * *$ & & & & \\
\hline & & & $(0.234)$ & & & & \\
\hline \multirow[t]{2}{*}{ Rules } & & & & -0.195 & & & \\
\hline & & & & $(0.372)$ & & & \\
\hline \multirow[t]{2}{*}{ Sustainability } & & & & & -0.368 & & \\
\hline & & & & & $(0.255)$ & & \\
\hline \multirow[t]{2}{*}{ comprehensiveness } & & & & & & -0.214 & \\
\hline & & & & & & $(0.224)$ & \\
\hline \multirow[t]{2}{*}{ Transparency } & & & & & & & -0.312 \\
\hline & & & & & & & $(0.236)$ \\
\hline \multirow[t]{2}{*}{ Constant } & $2.430 * * *$ & $2.379 * * *$ & $2.354 * * *$ & $2.429 * * *$ & $2.474 * * *$ & $2.460 * * *$ & $2.267 * * *$ \\
\hline & $(0.722)$ & $(0.632)$ & $(0.637)$ & $(0.706)$ & $(0.660)$ & $(0.691)$ & $(0.711)$ \\
\hline Observations & 40 & 40 & 40 & 40 & 40 & 40 & 40 \\
\hline R-squared & 0.412 & 0.472 & 0.502 & 0.419 & 0.445 & 0.430 & 0.449 \\
\hline
\end{tabular}

Robust standard errors in parentheses $* * * p<0.01, * * p<0.05, * p<0.1$ 
Table A-V 7: Central Government Primary Balance with IMF Programs

\begin{tabular}{|c|c|c|c|c|c|c|c|}
\hline & $\begin{array}{c}\text { WITHOUT } \\
\text { BI }\end{array}$ & WITH BI & CENTRALIZATION & RULES & "SUSTAINAB'Y & COMPREHENSIV'S & TRANSPARENCY \\
\hline VARIABLES & cgpb & cgpb & cgpb & cgpb & cgpb & cgpb & cgpb \\
\hline \multirow[t]{2}{*}{ Growth } & $-0.419 *$ & $-0.473^{*}$ & $-0.432 *$ & $-0.437^{*}$ & $-0.432 *$ & $-0.419 *$ & $-0.556^{* *}$ \\
\hline & $(0.225)$ & $(0.247)$ & $(0.236)$ & $(0.234)$ & $(0.236)$ & $(0.233)$ & $(0.257)$ \\
\hline \multirow[t]{2}{*}{ gdppc_2002 } & 0.00216 & 0.000454 & 0.00155 & 0.00153 & 0.00126 & 0.00217 & -0.00225 \\
\hline & $(0.00847)$ & $(0.00792)$ & $(0.00823)$ & $(0.00815)$ & $(0.00822)$ & $(0.00855)$ & $(0.00815)$ \\
\hline \multirow[t]{2}{*}{ Trade } & $0.225^{*}$ & $0.240 *$ & $0.222 *$ & $0.247 *$ & $0.250 *$ & $0.225 *$ & $0.230 *$ \\
\hline & $(0.117)$ & $(0.123)$ & $(0.118)$ & $(0.133)$ & $(0.131)$ & $(0.118)$ & $(0.122)$ \\
\hline \multirow[t]{2}{*}{ Resources } & $0.0436 * *$ & $0.0450 * *$ & $0.0442 * *$ & $0.0435 * *$ & $0.0439 * *$ & $0.0435 * *$ & $0.0446^{* * * *}$ \\
\hline & $(0.0165)$ & $(0.0168)$ & $(0.0174)$ & $(0.0168)$ & $(0.0168)$ & $(0.0172)$ & $(0.0157)$ \\
\hline \multirow[t]{2}{*}{ Fractionalization } & -0.00977 & -0.0119 & -0.00811 & -0.00810 & -0.0131 & -0.00968 & -0.0165 \\
\hline & $(0.0328)$ & $(0.0339)$ & $(0.0331)$ & $(0.0356)$ & $(0.0345)$ & $(0.0343)$ & $(0.0335)$ \\
\hline \multirow[t]{2}{*}{ Prgf } & 0.0136 & 0.0126 & 0.0128 & 0.0135 & 0.0135 & 0.0136 & 0.0116 \\
\hline & $(0.0151)$ & $(0.0151)$ & $(0.0138)$ & $(0.0149)$ & $(0.0152)$ & $(0.0149)$ & $(0.0150)$ \\
\hline \multirow[t]{2}{*}{ Index } & & 0.0347 & & & & & \\
\hline & & $(0.0429)$ & & & & & \\
\hline \multirow[t]{2}{*}{ Centralization } & & & 0.00816 & & & & \\
\hline & & & $(0.0381)$ & & & & \\
\hline \multirow[t]{2}{*}{ Rules } & & & & 0.0197 & & & \\
\hline & & & & $(0.0371)$ & & & \\
\hline \multirow[t]{2}{*}{ Sustainability } & & & & & 0.0186 & & \\
\hline & & & & & $(0.0310)$ & & \\
\hline \multirow[t]{2}{*}{ comprehensiveness_pca } & & & & & & -0.000377 & \\
\hline & & & & & & $(0.0251)$ & \\
\hline \multirow[t]{2}{*}{ Transparency } & & & & & & & $0.0485^{*}$ \\
\hline & & & & & & & $(0.0265)$ \\
\hline \multirow[t]{2}{*}{ Constant } & 0.00976 & 0.00859 & 0.00951 & 0.00365 & 0.00893 & 0.00981 & 0.0329 \\
\hline & $(0.0812)$ & $(0.0777)$ & $(0.0810)$ & $(0.0827)$ & $(0.0807)$ & $(0.0829)$ & $(0.0773)$ \\
\hline Observations & 40 & 40 & 40 & 40 & 40 & 40 & 40 \\
\hline R-squared & 0.387 & 0.398 & 0.388 & 0.392 & 0.392 & 0.387 & 0.441 \\
\hline
\end{tabular}

Robust standard errors in parentheses $* * * p<0.01, * * p<0.05, * p<0.1$ 